\title{
CEO Tournaments: A Cross-Country Analysis of Causes, Cultural Influences, and Consequences
}

\author{
Natasha Burns, Kristina Minnick, and Laura Starks*
}

\begin{abstract}
Using a cross-country sample, we examine the chief executive officer (CEO) tournament structure (measured alternatively as the ratio and the difference of pay between the CEO and other top executives within a firm). We find the tournament structure to vary systematically with firm and country cultural characteristics. In particular, firm size and the cultural values of power distance, fair income differences, and competition are significantly associated with variations in tournament structures. We also establish support for the primary implication of tournament theory in that tournament structure tends to be positively related to firm value, even after controlling for endogeneity.
\end{abstract}

\section{Introduction}

Tournaments can help spur the participants to ever higher levels of achievement, whether the tournament is among sports players, portfolio managers, or managers within a firm. ${ }^{1}$ Theory suggests that rank-order promotion tournaments in which the final (i.e., chief executive officer (CEO)) stage has a substantially higher level of compensation encourage competition, leading to better performance and, ultimately, higher firm value. Corporate promotion tournaments are considered important because of the incentives they provide for higher managerial performance throughout the firm (Lazear and Rosen (1981), Bognanno (2001)).

*Burns, natasha.burns@utsa.edu, College of Business, University of Texas at San Antonio; Minnick, kminnick@bentley.edu, Department of Finance, Bentley University; and Starks (corresponding author), 1starks@mail.utexas.edu, McCombs School of Business, University of Texas at Austin. We thank Hank Bessembinder, Wayne Ferson, Ron Giammarino, Jarrad Harford (the editor), Jay Hartzell, Mike Hertzel, Mark Huson, Jayant Kale (the referee), Arun Upadhyay, and John Wald, as well as participants at the 2012 University of Alberta Frontiers in Finance conference, the 2012 Eastern Finance Association conference, the 2014 Finance Down Under conference, the 2013 Financial Management Association conference, the 2012 Midwest Finance Association conference, the 2014 European Financial Management Association conference, and seminars at Bentley University, Erasmus University, and the U.S. Securities and Exchange Commission. Burns acknowledges support from the UTSA College of Business summer research grant. Tim Krause provided excellent research assistance.

${ }^{1}$ See, for example, Nalebuff and Stiglitz (1983), Lazear and Rosen (1981), Rosen (1986), Brown, Harlow, and Starks (1996), Bognanno (2001), Kale, Reis, and Venkateswaran (2009), Kempf, Ruenzi, and Thiele (2009), and Ramakrishnan and Thakor (1991). 
However, previous research based on single country analyses presents conflicting results regarding the association of firm value with CEO tournaments, with some finding a positive association (e.g., Kale et al. (2009)) and others finding no association or a negative association (e.g., Rajgopal and Srinivasan (2006), Bebchuk, Cremers, and Peyer (2011)). ${ }^{2}$

In this paper, we examine the CEO tournament structure across countries, incorporating cultural differences into the analysis. Such an approach allows us to bring a new identification strategy to the questions of whether CEO tournaments are a prevalent practice for providing incentives to CEOs, whether tournament structures are associated with country cultural values, and whether tournaments ultimately influence firm value within their cultural contexts.

Theory suggests that the incentives provided through a CEO tournament should depend on several important factors: the participants' endorsement of the tournament (i.e., their utility functions), the probability of winning (i.e., a random component), and the final prize (or steepness of the tournament). ${ }^{3}$ These attributes of a CEO tournament and its effects would be expected to be influenced by the cultural, economic, and legal environments in which it arises. Two critical foundations exist for our hypotheses on CEO tournaments across countries. First, the CEO tournament structure itself needs to be influenced by variations in cultural values. Second, these variations in cultural values also need to help explain why CEO tournaments could impact firm value differently across countries. That is, differences in tournament incentives and their effects need to derive, at least in part, from differences in cultural values.

With regard to the first foundation, we expect the level and structure of executive compensation to be influenced by cultural values since these values manifest in social systems, including corporate governance systems. For example, cultural differences are frequently given as the rationale for variations in CEO pay between the United States and other countries (e.g., Thomas (2004), Conyon and Murphy (2000)). ${ }^{4}$ These are consistent with Hofstede's (1980) arguments that differences in culture would be expected to influence how individuals think about corporate power structures and income inequality. Thus, we expect culture, that is, shared value, to affect decisions on compensation, and since culture varies across

\footnotetext{
${ }^{2}$ Specifically, Kale et al. (2009) find support for the empirical implications of tournament theory in U.S. data with their empirical evidence that firm value is positively associated with a measure of firm tournament structure. In contrast, other empirical research in the United States, for example, Rajgopal and Srinivasan (2006) and Bebchuk et al. (2011), using different data and measures, concludes that tournament pay is either not associated or negatively associated with higher firm value. Conyon, Peck, and Sadler (2001) examine implications of tournament theory in the United Kingdom. Although they find some results consistent with these implications, they do not find a positive association between their tournament pay measure and firm value.

${ }^{3}$ See, for example, Lazear and Rosen (1981), Green and Stokey (1983), and Rosen (1986). Green and Stokey (1983) show that optimal tournament structures dominate optimal independent contracts when the common shock is sufficiently diffuse or when there are a large number of participants, which are both regular conditions for a corporate tournament.

${ }^{4}$ In fact, the idea that country cultural values could affect CEO compensation structures and levels has not only been recognized by academics, but also by practitioners. For example, a Goldman Sachs GS SUSTAIN (2013) report on executive compensation refers to country norms in compensation in stating that divergence in compensation practices across countries will "likely be conditioned by country-relative norms" (p. 8).
} 
countries, we hypothesize that pay will vary with culture across countries. That is, the degree or acuteness of the tournament (the pay differential) is expected to be influenced by a society's opinion on such cultural values as the appropriateness of power structures and the fairness of income differentials due to differences in work.

The second necessary foundation for our hypotheses is the question of whether differences in tournament structures across countries, driven at least in part by cultural variations, lead to differences in tournament incentives and, ultimately, to differences in firm value. Thomas (2004) focuses on differences between compensation in the United States and other countries and argues that dispersed shareholder ownership and "winner-take-all" attitudes make larger tournament payoffs more acceptable in the United States than in other countries. He further points out that the winner-take-all culture (Frank and Cook (1995)), that is, the attitude that the winner of a competition is entitled to capture enormous benefits, makes the larger payoffs for U.S. CEOs more acceptable than abroad. Additionally, U.S. CEOs have more power than CEOs in other countries, which may create additional incentives for other executives to win the tournament (Thomas (2004)).

This competition to win the tournament is the catalyst in tournament theory for higher effort and more payoffs for firms (e.g., Lazear and Rosen (1981), Green and Stokey (1983), and Kale et al. (2009)). While Thomas (2004) confines his argument more broadly to differences between the United States and other countries, the same argument can be extended to differences across countries. Further, the differences in competition driven by differences in awards are tied to differences in cultural values, that is, individuals' perceptions of the importance of such aspects as power distance (measures of perceptions of equality in power distribution) and individualism (appreciation of the individual vs. the collective) and the extent to which people see income inequality as desirable, hard work and competition as rewarding, and the workplace as hierarchical. These cultural differences imply that societies may vary in how they weigh the advantages and disadvantages of CEO tournaments and, thus, their willingness to adopt such schemes as well as the executives' responses to the incentives, which provides implications for the relationship between tournament incentives and firm value. As we discuss later, there exist a number of arguments that tournaments can be counterproductive, resulting in loss of value for firms. Thus, an empirical test of the relation between firm value and tournament structures is necessary to distinguish among the sets of arguments.

We test whether CEO tournament structures across countries are related to their cultural, legal, and economic environments using data on CEO compensation and firm characteristics from Capital IQ (CIQ). Specifically, employing data on 8,103 firms in 14 countries across a 5-year sample period, we find systematic differences in the levels and tournament structures of executive pay across firms and countries. We employ univariate tests and find that U.S. CEOs are paid significantly more than non-U.S. CEOs, similar to the findings of other researchers (e.g., Fernandes, Ferreira, Matos, and Murphy (2013), Conyon, Core, and Guay (2011)). ${ }^{5}$ Moreover, we provide new evidence on cross-country comparisons of

\footnotetext{
${ }^{5}$ See Murphy $(1999,2013)$ for reviews of the executive compensation literature.
} 
executive compensation by showing that the U.S. univariate pay premium extends beyond the CEO: top executives just below the CEO receive higher compensation in the United States than do their counterparts in other countries.

We use several measures of a firm's tournament structure: the CEO_PAY_RATIO, which is the ratio of the CEO's compensation to the mean (median) of the other highest paid executives; the CEO_PAY_GAP, which is the absolute dollar difference in pay between the CEO and the average of the firm's next three highest paid executives (Bognanno (2001), Henderson and Fredrickson (2001), and Kale et al. (2009)); and the CEO_PAY_SLICE, which is the percentage the CEO claims of the total compensation to the top executive group (Bebchuk et al. (2011)). These tournament measures are primarily focused on internal promotions to CEO, which is in line with previous CEO succession studies that find the majority of CEOs are appointed from managers internal to the firm (e.g., Parrino (1997), Huson, Parrino, and Starks (2001) and Agrawal, Knoeber, and Tsoulouhas (2006)). ${ }^{6}$ We find each of these measures of CEO pay differential to be greater in the United States than in other countries, indicating a steeper tournament structure for U.S. executives. ${ }^{7}$ Using the measures in multivariate analyses to control for other explanatory variables, we test whether variations in CEO tournament structures across countries are associated with firm, cultural, economic, and legal characteristics. Similar to prior studies on absolute differences in CEO and other executive pay across countries, we show the differences in CEO tournament structures to also be related to firm characteristics.

We provide novel findings through the use of proxies for culture from Hofstede (1980), (2001) and the more recent 2005-2009 World Values Survey (WVS). Specifically, we find CEO tournaments are associated with Hofstede's POWER_DISTANCE measure, implying that the CEO tournament structure is reflective of the strength of the power structure in a society. We also find tournament structures to be significantly related to measures of a society's perceived desirability of income inequality and competition from the WVS. Although Hofstede's measures are derived from surveys taken a number of years ago, as we discuss later, a primary feature of the concept of cultural values is that they are embedded within a society and are slow moving. Moreover, our alternative culture measures from the WVS are contemporaneous with our compensation data.

We test the key implication of tournament theory, that is, the current CEO tournament structure should be related to future firm performance, which is reflected in the firm's current market value. We find a significant positive association between measures of tournament pay and Tobin's $q$ for firms in the worldwide sample overall; we also discover that the relation between the CEO tournament

${ }^{6}$ Fernandes et al. (2013) find the outside succession for non-U.S. firms to be higher but still less than $50 \%$. In the case of external hires, Coles, Li, and Wang (2013) argue for the existence of an industry tournament.

${ }^{7}$ Conyon and Murphy (2000) point out that divergence in levels of CEO pay between countries may be attributable to differences in option awards arising from cultural variations. However, the differences we document in the relative pay between CEOs and non-CEOs (the tournament) across countries remove the concern that we are simply measuring differences in the use of options across countries. If boards choose to provide the CEO with more options relative to non-CEOs, and that causes a steeper tournament structure, which derives from cultural values, we are measuring the effect of culture on the steepness of the tournament structure. 
and $q$ is heightened in the presence of cultural characteristics relating to competition, power distance, and positive perceptions of income differences. Larger tournaments are more positively associated with firm value in countries with common law origins: the United Kingdom, the United States, and Australia. ${ }^{8}$ It is also positively, though less strongly, associated with firm value in Germany, Hong Kong, India, and Switzerland. Interestingly, larger pay gaps in Canada and the Netherlands are negatively associated with firm value.

We also add novel findings to the literature by showing that cultural values appear to influence the effectiveness of a CEO tournament in improving firm performance. If competition is viewed more favorably in a country coupled with a steeper tournament, firm value appears to be further enhanced. We also find a tendency for firm value to increase under steeper CEO tournaments when a country's residents believe income differentials based on effort are fair outcomes.

This study is the first to provide a cross-country comparison of the CEO tournament structure, its determinants, and its association with firm value. Due to limited data availability, early research on cross-country CEO compensation largely relied on summary compensation measures or consultants' estimates and focused primarily on comparisons of CEO cash compensation. ${ }^{9}$ More recent research based on detailed data, for example, Fernandes et al. (2013), focuses on the cross-country differences in CEO compensation and explanations for those differences but does not consider CEO tournaments. ${ }^{10}$ Our study contributes to the existing body of literature on tournament structures cited above by providing analyses of the CEO tournament across countries and the relation of the tournament structure and consequences to firm and country characteristics, including cultural variables. Studying the ratio of the CEO's pay to that of other top executives in the same firm is advantageous, because it alleviates concerns that there exist unaccounted for firm and governance characteristics that affect the tournament. This is because within a given firm, the CEO and the other top executives are each exposed to the same economic, firm-specific, and governance factors.

We also contribute to the recent and growing literature on the influence of culture on economic outcomes. Our hypothesis that cultural values help drive firms' tournament structures is consistent with the Guiso, Sapienza, and Zingales (2009) argument and evidence that culture has an effect on individuals' preferences and beliefs, and these preferences, in turn, affect economic outcomes. Our hypothesis regarding CEO tournaments and culture is also consistent with other empirical research showing country cultural values to be associated with economic and financial outcomes. For example, Ahern, Daminelli, and Fracassi (2015) examine the role of culture in cross-border takeovers and find that dimensions of national culture (trust, hierarchy, and individualism) affect merger transactions in both the volume of mergers and the synergy gains from the mergers. They further find that cultural variables are related to the merger announcement returns. Frijns, Gilbert, Lehnert, and Tourani-Rad (2011) also explore culture and

\footnotetext{
${ }^{8}$ The results for the United States are consistent with those of Kale et al. (2009).

${ }^{9}$ See, for example, Kaplan (1994), Conyon and Murphy (2000), and Abowd and Kaplan (1999).

${ }^{10}$ Fernandes et al. (2013) conclude that the differences between the compensation of U.S. and other country CEOs reflect a risk premium for the greater use of option compensation in the United States.
} 
takeovers and conclude that the level of takeover activity in a country as well as the type of takeover undertaken is influenced by culture. ${ }^{11}$ In a contemporaneous paper, using a sample of firms cross-listed in the United States, Bryan, Nash, and Patel (2012) examine the relation of the elements of compensation to culture and conclude that country cultural characteristics are significant determinants of the relative use of equity-based compensation. ${ }^{12}$ Finally, the relation of tournament compensation structure to cultural factors is related to recent literature in finance on behavioral factors, CEO compensation, and actions (e.g., Malmiender and Tate (2005), Dittman, Maug, and Spalt (2010), Cronqvist, Makhija, and Yonker (2011), Gervais, Heaton, and Odean (2011), Graham, Harvey, and Puri (2013)). Our research contributes to this literature by providing a direct test of the role culture plays in economic outcomes through CEO tournament structures.

The rest of this paper proceeds as follows: In Section II, we describe our data and univariate results regarding CEO compensation and tournament structure. In Section III, we introduce our hypotheses regarding the relation between tournament structures and cultural values. In Section IV, we present our primary empirical results on the relation between tournament structure and firm value, and we provide conclusions in Section V.

\section{Cross-Country Comparisons of Executive Compensation and Tournament Structures}

\section{A. Data on Firm Characteristics}

We obtain data on individual firms' executive compensation from CIQ. Total compensation is defined as the sum of all compensation components for an executive, including salary, bonus, restricted stock, and options. We also employ CIQ data on the firm's size (measured as the log of revenue), leverage (measured as total debt to assets), profitability (ROA, measured as net income divided by assets), level of cash holdings (cash ratio, measured as cash to total assets), and institutional ownership. ${ }^{13}$ We derive the percent insider ownership from Datastream, which defines insiders as current and former directors, officers, and other private individuals owning more than $5 \%$ of the firm's shares. The primary sample contains 8,103 firms and 22,045 (8,671 are non-U.S. firms) firm-years over the period 2006-2010 for 14 countries. ${ }^{14}$ Table 1 shows the country and year breakout for our sample.

\footnotetext{
${ }^{11}$ Other papers that provide analyses of the influence of culture on financial outcomes include Stulz and Williamson (2003), Guiso, Sapienza, and Zingales (2008), Bogaard and Pirinsky (2011), Kumar, Page, and Spalt (2011), and Karolyi (2016).

${ }^{12}$ See, also, Guiso, Sapienza, and Zingales (2006), Li, Griffin, Yue, and Zhao (2013), Chui, Titman, and Wei (2010), Titman, Wei, and Xie (2013), Siegel, Licht, and Schwartz (2013), Ferris, Jayaraman, and Sabherwal (2013), Pan and Pirinsky (2015), Chen, Podolski, Rhee, and Veeraraghavan (2014), and Chen, Dou, Rhee, Truong, and Veeraraghavan (2015).

${ }^{13} \mathrm{CIQ}$ attempts to make the data consistent across countries; however, such an effort has obvious limitations due to differences in accounting practices across countries.

${ }^{14} \mathrm{We}$ include only the 14 countries that have at least 100 firm-year observations in the database. To reduce the influence of large outliers, we winsorize compensation and firm characteristic measures at the 5 th and 95 th percentiles.
} 
TABLE 1

Distribution of Observations

\begin{tabular}{|c|c|c|c|c|c|c|}
\hline Country & 2006 & 2007 & 2008 & 2009 & 2010 & Total \\
\hline Australia & 442 & 357 & 463 & 491 & 330 & 2,083 \\
\hline Canada & 198 & 174 & 145 & 89 & 43 & 649 \\
\hline China & 67 & 60 & 81 & 269 & 34 & 511 \\
\hline France & 79 & 95 & 121 & 91 & 31 & 417 \\
\hline Germany & 150 & 133 & 149 & 151 & 71 & 654 \\
\hline Hong Kong & 309 & 235 & 306 & 0 & 60 & 910 \\
\hline India & 12 & 11 & 18 & 72 & 3 & 116 \\
\hline Netherlands & 61 & 49 & 56 & 74 & 30 & 270 \\
\hline Norway & 45 & 39 & 32 & 50 & 12 & 178 \\
\hline South Africa & 126 & 82 & 108 & 0 & 54 & 370 \\
\hline Sweden & 47 & 33 & 46 & 51 & 8 & 185 \\
\hline Switzerland & 14 & 65 & 78 & 75 & 22 & 254 \\
\hline United Kingdom & 513 & 465 & 427 & 479 & 190 & 2,074 \\
\hline United States & 2,429 & 3,005 & 2,917 & 2,967 & 2,056 & 13,374 \\
\hline Total & 4,492 & 4,803 & 4,947 & 4,859 & 2,944 & 22,045 \\
\hline
\end{tabular}

\section{B. Executive Compensation}

A basic requirement for a firm's executive compensation structure to imply the existence of a tournament is that a significant differential should exist between the CEO's compensation and that of the next level of executives. Differences exist in our data with respect to executive compensation in non-U.S. countries as compared to the United States, as seen in Panel A of Table 2. In our sample, the average total compensation for U.S. CEOs is $\$ 2.5$ million, which is more than twice as high as the total compensation for non-U.S. CEOs of $\$ 927$ thousand, a difference that is both economically and statistically significant. The GS Sustain Report (2013) highlights the differences in the composition of the CEO's total compensation. For example, in 2012, the CEO of U.S.-based Chevron received $5.2 \%$ of his compensation from salary with no bonus, while the CEO of Netherlands-based Royal Dutch Shell received 34.9\% of his total compensation in salary and $64.8 \%$ in bonuses. The compositions of pay are quite varied across countries.

Panel A also shows the comparisons for the average compensation of the other top executives in a firm. As is the case for the CEOs, a U.S. pay premium exists for the total compensation of non-CEO executives. The result of pay premium differences between U.S. executives and executives of other countries is consistent with previous research, but as pointed out by Fernandes et al. (2013), it is important to analyze the pay premium in a multivariate framework, which we do in later analyses.

Tests of hypotheses on CEO tournament structures across firms and countries require a tournament measure that allows comparability across firms, industries, and, most importantly, countries and currencies. That is, because of the broader comparisons being made, we need some normalization of the tournament differential in pay in a firm. We employ two primary measures of tournament: the monetary pay gap between the CEO and other executives (Bognanno (2001), Henderson and Fredrickson (2001), Kale et al. (2009)) and the ratio of CEO pay to 
TABLE 2

Univariate Statistics for Differences in Compensation, Tournament Structures, and Firm Characteristics between U.S. and Non-U.S. Executives

Table 2 reports univariate statistics for executive compensation in the United States versus non-U.S. countries. Panel A shows total compensation in U.S. dollars for CEOs as well as the next top 3 executives in the firm. It also shows tournament measures that compare the CEO's compensation to that of the other executives: The CEO_PAY_RATIO (the total compensation of the CEO/mean compensation of other executives), the CEO_PAY_RATIO using the median compensation of other executives, the CEO PAY GAP (the difference in total compensation between the CEO and the median of other executives), the CEO_PAY_SLICE (the percentage of compensation for the top executives that goes to the CEO), CEO E PAY SLICE and CEO NE PAY SLICE (the percentage of equity and nonequity compensation for the top executives that goes to the CEO). Panel B provides means for the firm characteristics: REVENUE, ASSETS, MARKET_VALUE, NET_INCOME, LEVERAGE (Total Debt/Assets), ROA (EBIT/Assets), CASH_RATIO (Cash/Assets), TOBINS_Q (sum of MV of equity + BV of debt, divided by assets), \%_INSIDER (percentage of ownership held by insiders), and \%_INSTITUTION (percentage of ownership held by institutional investors). Each row shows the variable's mean and the number of observations for U.S. and non-U.S. observations. The final column of each row provides the results of $t$-tests of the differences between the U.S. and non-U.S. means. ${ }^{*}$, ${ }^{*}$, and ${ }^{* * *}$ indicate significance at the $10 \%, 5 \%$, and $1 \%$ levels, respectively.

\begin{tabular}{|c|c|c|c|c|c|}
\hline \multirow[b]{2}{*}{ Variables } & \multicolumn{2}{|c|}{ U.S. } & \multicolumn{2}{|c|}{ Non-U.S. } & \multirow{2}{*}{$\begin{array}{c}\text { Difference } \\
\text { (U.S. vs. } \\
\text { non-U.S.) }\end{array}$} \\
\hline & Mean & $N$ & Mean & $N$ & \\
\hline \multicolumn{6}{|l|}{ Panel A. CEO Tournament Measures } \\
\hline $\begin{array}{l}\text { CEO_TOTAL_COMPENSATION } \\
\text { TOP_3_NON-CEO_TOTAL_COMPENSATION } \\
\text { CEO_PAY_RATIO_WITH_MEAN } \\
\text { CEO_PAY_RATIO_WITH_MEDIAN } \\
\text { CEO_PAY_GAP (in \$millions) } \\
\text { CEO_PAY_SLICE (percentage of top pay) } \\
\text { CEO_E_PAY_SLICE } \\
\text { CEO_NE_PAY_SLICE }\end{array}$ & $\begin{array}{c}2,541,879 \\
1,469,645 \\
1.94 \\
2.12 \\
1.26 \\
0.36 \\
0.33 \\
0.302\end{array}$ & $\begin{array}{l}13,373 \\
13,373 \\
13,373 \\
13,373 \\
13,373 \\
13,373 \\
10,634 \\
13,371\end{array}$ & $\begin{array}{c}927,403 \\
873,815 \\
1.57 \\
1.69 \\
0.28 \\
0.33 \\
0.28 \\
0.30\end{array}$ & $\begin{array}{l}8,671 \\
8,671 \\
8,671 \\
8,671 \\
8,671 \\
8,671 \\
2,780 \\
8,669\end{array}$ & 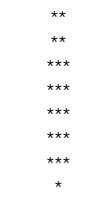 \\
\hline \multicolumn{6}{|l|}{ Panel B. Firm Characteristics } \\
\hline $\begin{array}{l}\text { REVENUE } \\
\text { ASSETS } \\
\text { MARKET_VALUE } \\
\text { NET_INCOME } \\
\text { LEVERAGE } \\
\text { ROA } \\
\text { CASH_RATIO } \\
\text { TOBINS_Q } \\
\text { \%_INSIDERS } \\
\text { \%_INSTITUTION }\end{array}$ & $\begin{array}{r}2,361 \\
5,541 \\
2,900 \\
161 \\
0.22 \\
0.01 \\
0.12 \\
1.24 \\
12.26 \\
45.15 \\
\end{array}$ & $\begin{array}{l}13,373 \\
13,373 \\
13,373 \\
13,373 \\
13,373 \\
13,373 \\
13,373 \\
13,373 \\
13,373 \\
13,373 \\
\end{array}$ & $\begin{array}{c}3,079 \\
9,283 \\
3,735 \\
265 \\
0.18 \\
0.04 \\
0.12 \\
1.14 \\
18 \\
20.11 \\
\end{array}$ & $\begin{array}{l}8,671 \\
8,671 \\
8,671 \\
8,671 \\
8,671 \\
8,671 \\
8,671 \\
8,671 \\
8,671 \\
8,671 \\
\end{array}$ & 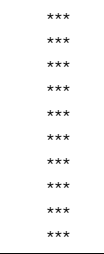 \\
\hline
\end{tabular}

the other executives' pay. ${ }^{15}$ Although the two measures both capture a differential in pay, they also highlight somewhat diverse aspects of the differential. The pay gap measure captures the importance of the ultimate size of the prize, such that working for a larger firm may result in a bigger prize (e.g., Coles et al. (2013)). However, variables that explain variation in the level of pay across countries may also explain the pay gap; therefore, we also use the mean and median pay ratio, which is independent of the level of pay or firm size. ${ }^{16}$ In addition, for comparison, we show the alternative measures of pay slice used in Bebchuk et al. (2011).

In Panel A of Table 2, we provide summary statistics on the measures of the tournament structure separately for U.S. and non-U.S. firms. Examining the CEO_PAY_RATIO, we find that the tournament structure is greater for U.S. CEOs

${ }^{15}$ We use the 3 top executives under the CEO rather than the 4 top executives common in the U.S. literature, because the average number of other top executives for which data are available in other countries is 3 .

${ }^{16}$ The pay gap is closely related to the level of compensation. For instance, if CEOs get paid $50 \%$ more than non-CEOs, then the difference will be linearly related to the level of pay. Thus, variables that explain level of pay will also explain the difference, whereas our interest is in measuring inequality in pay, not just the levels. On the other hand, the pay ratio ignores scale effects. However, as noted, scale is also important; therefore, we use both measures. 
than for non-U.S. CEOs: U.S. CEOs make 1.94 (2.12) times the mean (median) top executive, while non-U.S. CEOs make 1.57 (1.69) times the mean (median) top executive.

Using the pay gap (the difference between the CEO's pay and the median of other top executives' pay), we find, similar to Kale et al. (2009), U.S. CEO compensation is significantly higher than the median compensation of the firm's other top executives by an average of $\$ 1.26 \mathrm{M}$. We also find a tournament structure in the non-U.S. countries but to a lesser absolute degree, with the difference between the CEO and other executives being $\$ 0.28 \mathrm{M}$.

The next measure shown in Table 2 is the CEO_PAY_SLICE measure, that is, the percentage of top executive compensation paid to the CEO. Not surprisingly, consistent with the pay ratio and pay gap measures, we find the CEO_PAY_SLICE to be slightly higher in the United States than in other countries. However, as Table 2 shows, the economic significance of the difference is low, given that $36 \%$ and $33 \%$ of the top executive pay goes to the CEO in the U.S. and non-U.S. countries, respectively. Similar to the Bebchuk et al. (2011) process for their U.S. sample, we separate the CEO_PAY_SLICE measure into its equity and nonequity components. The measure of the CEO's slice of equity compensation, denoted CEO_E, shows that of those firms that pay their executives with equity, $33 \%$ of the equity-based incentive compensation goes to the CEO, in contrast to $28 \%$ to the CEO in non-U.S. countries. ${ }^{17}$ Correspondingly, the CEO's slice of nonequity compensation, denoted CEO_NE, is also greater in the United States relative to other countries, but to a lesser degree. It is important to note that the pay ratio and pay slice measures address concerns regarding purchasing power parity since they are measured as the percentages of executive pay in the same country, and comparisons of tournaments across countries are made using these measures. In summary, U.S. CEOs are paid more than non-U.S. CEOs relative to other top executives in their firms, but they also appear to take on more risk in their compensation through their incentive compensation structure, which is consistent with the earlier results of Fernandes et al. (2013).

Panel B describes the characteristics of the firms in our sample. The average revenue of U.S. (non-U.S.) firms is $\$ 2.36$ billion ( $\$ 3.08$ billion). Our sample of U.S. firms includes smaller firms than that of other studies on U.S. compensation. The other measures of size, including assets and market value, also show that the average non-U.S. firm in our sample is larger than the U.S. firms. This is striking because average compensation for U.S. firms in the univariate analysis is larger than that for non-U.S. firms. Tobin's $q$ is an average of 1.24 for U.S. firms and 1.14 for non-U.S. firms. Not surprisingly, given the differences in ownership structure across countries, insider ownership is lower and institutional ownership is higher in the United States as compared to other countries.

Table 3 presents the same statistics as in Table 2 but using the subset of CIQ firms that are in the top tercile of size to facilitate comparison with previous

\footnotetext{
${ }^{17}$ Because this measure is valid only for those firms that use equity-based compensation, and many non-U.S. firms do not employ such compensation, the sample size for the non-U.S. firms reduces to 2,888 .
} 
TABLE 3

Univariate Statistics for Differences in Compensation, Tournament Structures, and Firm Characteristics between U.S. and Non-U.S. Executives for the Largest Firms

Table 3 reports univariate statistics for executive compensation in the United States and in non-U.S. countries for the tercile of sample firms with the greatest revenue. Panel A shows total compensation in U.S. dollars for CEOs as well as the next top 3 executives in the firm. It also shows tournament measures that compare the CEO's compensation to that of the other executives: the CEO_PAY_RATIO (the total compensation of the CEO/mean compensation of other executives), the CEO PAY RATIO using the median compensation of other executives, the CEO PAY_GAP (the difference in total compensation between the CEO and the median of other executives), the CEO_PAY_SLICE (the percentage of compensation for the top executives that goes to the CEO), CEO_E_PAY_SLICE and CEO_NE_PAY_SLICE (the percentage of equity and nonequity compensation for the top executives that goes to the CEO). Panel B provides means for the firm characteristics: REVENUE, ASSETS, MARKET_VALUE, NET_INCOME, LEVERAGE (Total Debt/Assets), ROA (EBIT/Assets), CASH_RATIO (Cash/Assets), TOBINS_Q (sum of MV of equity + BV of debt, adjusted by assets), \%_INSIDERs, and \% INSTITUTION. Each row shows the mean and number of observations for U.S. and non-U.S. observations. The final column of each row provides the results of $t$-tests of the differences between the U.S. and non-U.S. means. ${ }^{*}$, ${ }^{*}$, and ${ }^{* * *}$ indicate significance at the $10 \%, 5 \%$, and $1 \%$ levels, respectively.

\begin{tabular}{|c|c|c|c|c|c|}
\hline \multirow[b]{2}{*}{ Variables } & \multicolumn{2}{|c|}{ U.S. } & \multicolumn{2}{|c|}{ Non-U.S. } & \multirow{2}{*}{$\begin{array}{c}\text { Difference } \\
\text { (U.S. vs. } \\
\text { non-U.S.) }\end{array}$} \\
\hline & Mean & $N$ & Mean & $N$ & \\
\hline \multicolumn{6}{|l|}{ Panel A. Tournament Measures } \\
\hline $\begin{array}{l}\text { CEO_TOTAL_COMPENSATION } \\
\text { TOP_3_NON-CEO_TOTAL_COMPENSATION } \\
\text { CEO_PAY_RATIO_WITH_MEAN } \\
\text { CEO_PAY_RATIO_WITH_MEDIAN } \\
\text { CEO_PAY_GAP (in \$millions) } \\
\text { CEO_PAY_SLICE (percentage of top pay) } \\
\text { CEO_E_PAY_SLICE } \\
\text { CEO_NE_PAY_SLICE }\end{array}$ & $\begin{array}{c}5,062,705 \\
2,267,085 \\
2.08 \\
2.30 \\
2.05 \\
0.36 \\
0.33 \\
0.297\end{array}$ & $\begin{array}{l}7,129 \\
7,129 \\
7,129 \\
7,129 \\
7,129 \\
7,129 \\
6,304 \\
7,129\end{array}$ & $\begin{array}{c}1,595,141 \\
1,498,510 \\
1.50 \\
1.61 \\
0.48 \\
0.31 \\
0.27 \\
0.281\end{array}$ & $\begin{array}{l}3,893 \\
3,893 \\
3,893 \\
3,893 \\
3,893 \\
3,893 \\
1,247 \\
3,893\end{array}$ & 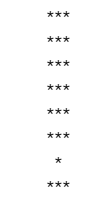 \\
\hline \multicolumn{6}{|l|}{ Panel B. Firm Characteristics } \\
\hline $\begin{array}{l}\text { REVENUE } \\
\text { ASSETS } \\
\text { MARKET_VALUE } \\
\text { NET_INCOME } \\
\text { LEVERAGE } \\
\text { ROA } \\
\text { CASH_RATIO } \\
\text { TOBINS_Q } \\
\text { \%_INSIDERS } \\
\text { \%_INSTITUTION }\end{array}$ & $\begin{array}{c}4,304 \\
10,260 \\
5,295 \\
303.10 \\
0.25 \\
0.07 \\
0.07 \\
1.06 \\
7.58 \\
60.39\end{array}$ & $\begin{array}{l}7,129 \\
7,129 \\
7,129 \\
7,129 \\
7,129 \\
7,129 \\
7,129 \\
7,129 \\
7,129 \\
7,129 \\
\end{array}$ & $\begin{array}{c}6,692 \\
20,511 \\
8,155 \\
582.66 \\
0.22 \\
0.08 \\
0.09 \\
1.01 \\
14.46 \\
27.74 \\
\end{array}$ & $\begin{array}{l}3,893 \\
3,893 \\
3,893 \\
3,893 \\
3,893 \\
3,893 \\
3,893 \\
3,893 \\
3,893 \\
3,893 \\
\end{array}$ & 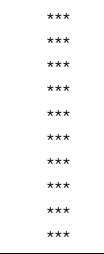 \\
\hline
\end{tabular}

studies of U.S. compensation. The average revenue of this U.S. (non-U.S.) subsample is $\$ 4.3$ billion ( $\$ 6.7$ billion). Similarly, total compensation for U.S. (nonU.S.) CEOs is greater at $\$ 5 \mathrm{M}(1.6 \mathrm{M})$. The difference between U.S. and non-U.S. compensation is even greater than that reported in Table 2, suggesting that U.S. pay might be more sensitive to firm size. The compensation of other executives is also greater in the United States. In general, the results in Table 3 mirror those in Table 2, but the differences between the U.S. and non-U.S. compensation variables are somewhat magnified.

\section{Firm Characteristic Determinants of CEO Tournament Structures across Countries}

In this section, we examine whether, on a global basis, CEO tournament structure can be explained by firm characteristics, given that Kale et al. (2009) found this to be the case for U.S. firms. Table 4 presents the determinants of the CEO tournament structure in a multivariate framework. The dependent variables in models 1 and 2 are the CEO pay ratios (ratio of the CEO compensation to mean and median top executive non-CEO compensation, respectively). In model 3, we examine the CEO_PAY_GAP, that is, the difference between the CEO and median 
TABLE 4

\section{CEO Tournament Structures}

Table 4 shows the multivariate estimation where the dependent variable is a measure of the CEO tournament structure and the independent variables are potential determinants, all of which are lagged 1 year. The different tournament measures compare the CEO's compensation to that of the top three other executives: (model 1) the CEO_PAY_RATIO using total compensation of CEO/mean total compensation of other executives, (model 2) the CEO PAY RATIO using total compensation of CEO/median total compensation of other executives, (model 3) the CEO_PAY_SLICE (the percentage of compensation for top executives that goes to the CEO), (model 4) the CEO_PAY_GAP (the difference in total compensation between the CEO and the median of other executives), (model 5) CEO_E_PAY_SLICE (the percentage of compensation for the top executives that goes to the CEO), and (model 6) CEO_NE_PAY_SLICE (the percentage of equity and nonequity compensation for the top executives that goes to the CEO). The regressions also include firm characteristics: U.S. firm (an indicator for whether the firm is headquartered in the United States), REVENUE, ASSETS, MARKET_VALUE, NET_INCOME, LEVERAGE (Total Debt/Assets), ROA (EBIT/Assets), CASH_RATIO (Cash/Assets), TOBINS_Q (sum of MV of equity + BV of debt, divided by assets), \%_INSIDER (percentage of ownership held by insiders), and \%_INSTITUTION (percentage of ownership held by institutional investors). Models 7 and 8 also include additional firm characteristics available for a smaller subsample of the firms, including CEO_AGE, BOARD_SIZE, \%_INDEP (percentage of directors that are independent), and CEO/CHAIR (an indicator for whether the CEO is also chairman of the board). For each variable, the coefficient is reported on the first line with the $p$-value below in parentheses. We control for robust standard errors clustered by firm as well as country, industry, and year fixed effects. ${ }^{\star},{ }^{\star *}$, and ${ }^{* \star *}$ indicate significance at the $10 \%, 5 \%$, and $1 \%$ levels, respectively.

\begin{tabular}{|c|c|c|c|c|c|c|c|c|}
\hline \multirow{3}{*}{$\begin{array}{l}\text { Independent } \\
\text { Variable }\end{array}$} & \multicolumn{8}{|c|}{ Dependent Variable } \\
\hline & $\begin{array}{c}\text { Pay Ratio } \\
\text { Mean }\end{array}$ & $\begin{array}{c}\text { Pay Ratio } \\
\text { Median }\end{array}$ & $\begin{array}{l}\text { Pay } \\
\text { Gap }\end{array}$ & $\begin{array}{l}\text { Pay } \\
\text { Slice }\end{array}$ & $\begin{array}{l}\text { E Pay } \\
\text { Slice }\end{array}$ & $\begin{array}{l}\text { NE Pay } \\
\text { Slice }\end{array}$ & $\begin{array}{c}\text { Pay Ratio } \\
\text { Mean }\end{array}$ & $\begin{array}{l}\text { Pay } \\
\text { Gap }\end{array}$ \\
\hline & 1 & 2 & 3 & 4 & 5 & 6 & 7 & 8 \\
\hline U.S. firm & $\begin{array}{l}0.302^{* \star \star} \\
(0.00)\end{array}$ & $\begin{array}{l}0.378^{\star \star \star} \\
(0.00)\end{array}$ & $\begin{array}{l}0.696^{\star \star *} \\
(0.00)\end{array}$ & $\begin{array}{l}0.013^{\star \star \star} \\
(0.00)\end{array}$ & $\begin{array}{l}0.026^{\star \star *} \\
(0.00)\end{array}$ & $\begin{array}{r}-0.007 \\
(0.12)\end{array}$ & $\begin{array}{l}0.244^{\star \star \star} \\
(0.00)\end{array}$ & $\begin{array}{l}0.596^{\star \star \star} \\
(0.00)\end{array}$ \\
\hline $\log (R E V E N U E)$ & $\begin{array}{c}-0.012^{*} \\
(0.05)\end{array}$ & $\begin{array}{c}-0.003 \\
(0.78)\end{array}$ & $\begin{array}{l}0.231^{\star \star *} \\
(0.00)\end{array}$ & $\begin{array}{l}-0.006^{\star \star \star} \\
(0.00)\end{array}$ & $\begin{array}{l}-0.007^{\star \star *} \\
(0.00)\end{array}$ & 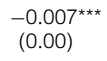 & $\begin{array}{c}0.020 \\
(0.24)\end{array}$ & $\begin{array}{l}0.341^{\star \star \star} \\
(0.00)\end{array}$ \\
\hline LEVERAGE & $\begin{array}{c}0.074 \\
(0.28)\end{array}$ & $\begin{array}{c}0.087 \\
(0.26)\end{array}$ & $\begin{array}{c}0.127 \\
(0.20)\end{array}$ & $\begin{array}{c}0.002 \\
(0.78)\end{array}$ & $\begin{array}{c}0.011 \\
(0.42)\end{array}$ & $\begin{array}{c}0.001 \\
(0.97)\end{array}$ & $\begin{array}{c}0.013 \\
(0.91)\end{array}$ & $\begin{array}{c}-0.103 \\
(0.57)\end{array}$ \\
\hline CASH_RATIO & $\begin{array}{c}0.061 \\
(0.54)\end{array}$ & $\begin{array}{c}0.088 \\
(0.45)\end{array}$ & $\begin{array}{l}0.507^{\star \star \star} \\
(0.00)\end{array}$ & $\begin{array}{l}-0.032^{\star \star} \\
(0.02)\end{array}$ & $\begin{array}{l}-0.048^{\star *} \\
(0.02)\end{array}$ & $\begin{array}{l}-0.039^{\star \star \star} \\
(0.00)\end{array}$ & $\begin{array}{l}-0.332^{\star \star} \\
(0.04)\end{array}$ & $\begin{array}{l}0.664^{\star \star \star} \\
(0.01)\end{array}$ \\
\hline $\log (G N P)$ & $\begin{array}{l}-0.107^{* *} \\
(0.02)\end{array}$ & $\begin{array}{l}-0.144^{\star * *} \\
(0.01)\end{array}$ & $\begin{array}{l}0.048^{*} \\
(0.05)\end{array}$ & $\begin{array}{c}-0.001 \\
(0.89)\end{array}$ & $\begin{array}{c}-0.004 \\
(0.77)\end{array}$ & $\begin{array}{c}-0.001 \\
(0.75)\end{array}$ & $\begin{array}{c}-0.153 \\
(0.24)\end{array}$ & $\begin{array}{l}0.228^{\star \star \star} \\
(0.00)\end{array}$ \\
\hline \%_INSIDERS & $\begin{array}{l}0.002^{* \star} \\
(0.02)\end{array}$ & $\begin{array}{l}0.003^{\star \star \star} \\
(0.00)\end{array}$ & $\begin{array}{l}-0.003^{\star \star \star} \\
(0.00)\end{array}$ & $\begin{array}{l}0.001^{\text {**}} \\
(0.00)\end{array}$ & $\begin{array}{c}0.001 \\
(0.40)\end{array}$ & $\begin{array}{l}0.001^{\text {** }} \\
(0.00)\end{array}$ & $\begin{array}{c}0.002 \\
(0.22)\end{array}$ & $\begin{array}{c}-0.003 \\
(0.23)\end{array}$ \\
\hline \%_INSTITUTION & $\begin{array}{l}0.004^{\star \star \star} \\
(0.00)\end{array}$ & $\begin{array}{l}0.004^{\star \star *} \\
(0.00)\end{array}$ & $\begin{array}{l}0.009^{\star \star \star} \\
(0.00)\end{array}$ & $\begin{array}{l}0.001^{\star \star \star} \\
(0.00)\end{array}$ & $\begin{array}{l}0.001^{\star \star *} \\
(0.00)\end{array}$ & $\begin{array}{l}0.001^{\star \star} \\
(0.01)\end{array}$ & $\begin{array}{l}0.003^{\star \star \star} \\
(0.00)\end{array}$ & $\begin{array}{l}0.006^{\star \star \star} \\
(0.00)\end{array}$ \\
\hline CEO_AGE & & & & & & & $\begin{array}{c}-0.005 \\
(0.21)\end{array}$ & $\begin{array}{c}-0.010^{\star \star} \\
(0.05)\end{array}$ \\
\hline BOARD_SIZE & & & & & & & $\begin{array}{l}-0.040^{\star \star \star} \\
(0.00)\end{array}$ & $\begin{array}{c}-0.040^{\star *} \\
(0.04)\end{array}$ \\
\hline$\%$ \%_INDEP & & & & & & & $\begin{array}{l}0.787^{\text {}} \\
(0.00)\end{array}$ & $\begin{array}{l}1.431^{\star \star \star} \\
(0.00)\end{array}$ \\
\hline $\mathrm{CEO} / \mathrm{CHAIR}$ & & & & & & & $\begin{array}{l}0.091^{\star} \\
(0.09)\end{array}$ & $\begin{array}{l}0.369^{\star \star \star} \\
(0.00)\end{array}$ \\
\hline Constant & $\begin{array}{l}2.363^{\star \star \star} \\
(0.00)\end{array}$ & $\begin{array}{l}2.772^{\star \star \star} \\
(0.00)\end{array}$ & $\begin{array}{l}-1.883^{\text {***}} \\
(0.00)\end{array}$ & $\begin{array}{l}0.300^{\star \star \star} \\
(0.00)\end{array}$ & $\begin{array}{l}0.311^{\star *} \\
(0.02)\end{array}$ & $\begin{array}{l}0.301^{\star \star \star} \\
(0.00)\end{array}$ & $\begin{array}{l}2.784^{\star \star} \\
(0.05)\end{array}$ & $\begin{array}{c}-5.267^{\star \star \star} \\
(0.00)\end{array}$ \\
\hline No. of obs. & 22,045 & 22,045 & 22,045 & 22,045 & 13,415 & 22,045 & 9,525 & 9,525 \\
\hline Adj. $R^{2}$ & 0.040 & 0.038 & 0.178 & 0.070 & 0.042 & 0.059 & 0.051 & 0.196 \\
\hline
\end{tabular}

other executive pay. In model 4, the dependent variable is the CEO_PAY_SLICE, the percentage of total compensation that goes to the CEO. In model 5, we examine how equity compensation is used in the United States relative to other countries for the subset of firms that use options or restricted stock to compensate executives, while model 6 measures the use of nonequity compensation. In models 7 and 8, we include additional firm characteristics as explanatory variables for a much smaller subset of the sample. In all eight models, we control for country, industry, and year fixed effects. We cluster standard errors by firm.

In the first four regressions of the CEO tournament structure, the indicator variable U.S. is positive and significant in all specifications. Thus, consistent with 
the univariate results in Tables 2 and 3, even after controlling for other firm characteristics, we find that, relative to other countries, U.S. CEOs on both absolute and relative bases have larger pay differentials from their top management teams, suggesting a steeper tournament structure in the United States. For instance, in model 1, U.S. CEOs have a $30 \%$ higher tournament advantage as compared to other countries. Models 5 and 6 provide some insight into this dichotomy between the United States and other countries, as they show the tournament pay slice for equity and nonequity compensation, respectively. The U.S. indicator variable in model 5 is significant at the $1 \%$ level, while it is insignificant in model 6 . These results suggest that the large differences in tournament pay between the United States and other countries are driven by U.S. CEOs receiving relatively more equity compensation than their deputies, as compared to their counterparts in other countries.

In terms of the association of CEO tournaments with firm characteristics, we find that in most specifications, the steepness of the tournament structure is related to the size of the firm (as measured by the log(REVENUE)). However, the signs vary by whether we use an absolute or relative measure of the tournament structure. When using a relative measure (CEO_PAY_RATIO or CEO_PAY_SLICE), we find the structure to be less steep for the larger firms. On the other hand, when using the absolute tournament measure (CEO_PAY_GAP), we find the structure to become steeper in large firms. This result is consistent with earlier findings for U.S. firms (Kale et al. (2009)).

We find that greater insider ownership increases the relative tournament measure (models 1, 2, 4, and 6), which is consistent with Mehran's (1995) finding that insider ownership is related to incentive compensation. However, we do not find this to be the case for the absolute tournament measure, which decreases with insider ownership.

Since institutional ownership has been shown to have a positive relation with incentive compensation in a firm (Hartzell and Starks (2003)), we expect it to have a positive effect on tournament structure, which is a form of incentive compensation structure. Consistent with this expectation, we find the relation between tournament structure and institutional ownership to be positive and significant in all regressions.

In the final two regressions, we check whether our results are robust to controlling for $\mathrm{CEO}$ and board characteristics shown in previous research to have an association with CEO compensation. ${ }^{18}$ These data are obtained from BoardEx, and the sample size decreases by more than $60 \%$ after conditioning on availability of data; $96 \%$ of the remaining observations are from the United States, United Kingdom, and Australia, leaving little country variation. Similar to Bebchuk et al.'s (2011) findings using CEO_PAY_SLICE, we find the CEO tournament structure to be negatively related to BOARD_SIZE; that is, steeper tournaments are more likely for firms with smaller boards. There is also a significantly positive coefficient on independent boards and CEO duality. The coefficient on the

\footnotetext{
${ }^{18}$ See Yermack (1996) and Core, Holthausen, and Larcker (1999) on board size, Hartzell and Starks (2003) on independence, and Core et al. (1999), Goyal and Park (2002), Cyert, Kang, and Kumar (2002), and Conyon and Murphy (2000) on CEO duality.
} 
percentage of the board that is independent is positive, consistent with earlier results for U.S. firms for which pay dispersion (as measured by the coefficient of variation of the top management team's compensation) is related to board independence (Lee, Lev, and Yeo (2008)). This result can reflect the board's attempt to increase incentives from the tournament in order to improve firm performance. CEOs who are also board chairs may have more power to influence their compensation relative to the other executives. More central to our paper, the result that the CEO tournament structure is steeper in the United States continues to hold after inclusion of these governance variables, even in comparison to countries that seem very similar to the United States. These results are consistent with Thomas' (2004) hypothesis that compensation constraints are greater in the United Kingdom and Australia than in the United States.

\section{CEO Tournament Structure and Cultural Values}

In this section, we develop hypotheses regarding the potential relationship between culture and CEO tournament structures. We expect that the steepness of the tournament structure as well as the motivations and consequences it initiates should be related not only to firm characteristics (e.g., Kale et al. (2009)), but also to the country cultural values. We then present the major country cultural and economic characteristics expected to be related to CEO tournament structures.

\section{A. Hypotheses on the Interrelation of Tournaments with Cultural Values}

The argument for the existence of a managerial tournament arises from the inability of the shareholders (or the board of directors) to monitor managers perfectly. For example, Lazear and Rosen (1981) maintain that a promotion rankorder tournament with executive pay disparity provides incentives for managers to perform at higher levels because of the opportunities to move up in the organization, which benefits the firm. That is, the large differences in compensation between positions on the corporate ladder will provide motivation for higher managerial performance, resulting in greater firm value. Thus, managerial effort should be positively associated with the size of the pay differential, which can lead to better firm performance, assuming that firm performance is increasing in managerial effort. Further, at the top of the ladder (CEO vs. executives directly under the CEO), these pay differentials need to be even greater due to the end stage of the game (Rosen (1986)).

Our hypotheses concerning the influence of cultural values on the CEO tournament structure are supported, in part, by previous preliminary empirical research. Using a consulting firm's estimates of aggregate measures of CEO compensation at the country level for 23 countries from 1997 to 2001, Tosi and Greckhamer (2004) provide a rough estimate of the relation between Hofstede's (1980), (2001) cultural values and compensation. They conclude that aggregate country measures of compensation are positively related to a country's POWER_DISTANCE and INDIVIDUALISM scores, implying that CEO pay is reflective of the strength of the power structure in a society as well as the extent to which individual needs are considered more important than group needs. 
Evidence has supported the hypothesis that public concern over compensation affects pay and votes on pay. ${ }^{19}$ As Thomas (2004) points out, numerous examples of constraints on pay exist across multiple countries. These include the $\$ 1 \mathrm{M}$ cap on the deductibility of nonperformance-based compensation in the United States (Murphy (1999)), "Say-on-Pay" initiatives, the Greenbury director compensation report in the United Kingdom (Cheffins (1997)), and legal requirements that executive pay be "reasonable in Australia and Germany" (Cheffins (1997)). All of these examples of compensation constraints could be influenced by culture. In fact, Thomas points out that even in countries with similar governance systems to the United States, such as Australia, Canada, and the United Kingdom, there exists an aversion to high executive pay, which he attributes to cultural differences.

Baker, Jensen, and Murphy (1988) argue that tournament promotion is not without problems, because there may not be proper matching of talents from the previous position to the future position. Henderson and Fredrickson (2001) argue and provide supporting evidence from the United States that CEO tournaments conform to both the economic view that large pay gaps create incentives and the behavioral view that greater coordination needs in firms encourage smaller pay gaps because the more equal pay promotes collaboration. Thomas (2004) points out that the loser of the tournament may leave the firm, increasing turnover and harming retention and cooperation. ${ }^{20}$ Consistent with this hypothesis, Kale, Reis, and Venkateswaran (2014) find that managerial turnover in the United States is higher with greater pay inequality. All three of these related points imply that societies in which employees are expected to remain at a firm long term and be part of a team should view tournaments differently from other cultures; further, while CEO tournaments may be beneficial for firm operations (and value) in some countries, in other countries, they may be counterproductive.

As discussed below, the effectiveness of tournaments may be driven by cultural differences across countries, especially a country's views on power, individualism, income differences and inequality, hard work, and competition.

\section{Hofstede Measures of Culture}

Hofstede argues that cultural values are formed through early socialization and are long lasting. Thus, he characterizes these values through a set of dimensions according to national origin. Hofstede's (1980), (2001) cultural value dimensions, although measured a number of years ago, are considered to be longlived. This is consistent with the Guiso et al. (2006) definition of culture, "those customary beliefs and values that ethnic religious and social groups transmit fairly unchanged from generation to generation." Similarly, Becker (1996) suggests that culture changes slowly over time.

Bebchuk et al. (2011) suggest that the disparity in pay between the CEO and the other executives should reflect whether the firm has a team or dominant leadership style. Thomas (2004) argues that the dispersed ownership structure of U.S. companies gives U.S. CEOs more power relative to shareholder-control dominated systems, implying that U.S. CEOs should be paid more. He goes on to

\footnotetext{
${ }^{19}$ See, for example, Bebchuk, Fried, and Walker (2003), Thomas (2004), Ertimur, Ferri, and Muslu (2011), Kuhnen and Niessen (2012), Murphy (2013), and Aggarwal, Erel, and Starks (2015).

${ }^{20}$ See also Henderson and Fredrickson (2001).
} 
argue that the use of tournaments should be more important in the United States, since U.S. CEOs can be more powerful or have greater authority than non-U.S. CEOs. In a similar vein, Aoki (1990), using Japanese firms as an example, emphasizes the importance of consensus among managers in the decisions of the firm, in contrast to that of the United States where there is more hierarchical separation. To capture this cultural factor across countries, we use Hofstede's (1980), (2001) power distance measure.

The POWER_DISTANCE index, which measures perceptions of equality in the distribution of power in a society, is calculated based on three questions from the Hofstede survey. This index has been found to be relevant to a number of different aspects of work life and employee motivation. For example, Schwartz (1999) examines the influence of prevailing cultural values on the meaning of work for individuals and concludes that in countries with higher power distance, employees prefer hierarchical companies because of the consequent motivation to move up the corporate ladder. Further, Surkov (2014) argues that if a typical citizen in a country is accepting of power inequalities and highly regards a distinct hierarchical system, then the nation may be more likely to have greater imbalances in wealth, all else being equal. Such results imply that in cultures where power is more acceptable, tournaments may be more prevalent, as tournaments promote power inequality and provide hierarchical incentives to be promoted.

Similarly, the extent to which individuals' goals and accomplishments are seen as more important than society's goals and accomplishments could also lead to steeper tournaments. For this cultural attribute, we employ Hofstede's (1980), (2001) individualism measure. The individualism measure captures the degree to which a society appreciates the individual versus the collective. Dodor, and Rana (2007) suggest that individualism positively correlates with GINI per capita and resource allocation efficiency, which occurs because individuals are more likely to increase total national wealth by pursuing their own interests. This suggests that the degree of individualism may be related to the use and effectiveness of tournaments.

\section{WVS Measures of Culture}

Our other measures of cultural values are based on questions from the 20052009 WVS that are roughly coincident with our compensation data. The WVS has been developed by "a worldwide network of social scientists studying changing values and their impact on social and political life." These scientists conduct representative national surveys in 97 societies containing almost $90 \%$ of the world's population. The surveys, which are conducted in person, have been administered in 4-year waves since 1981. Although cultural values change very slowly over time, because we know the year in which a particular country is surveyed, we match the most recent measure of a cultural item from the WVS to the year of the compensation data. The major advantages of the WVS data relative to the Hofstede (1980) data are that the survey is more recent and it covers a broader set of countries. Ahern et al. (2015) discuss the construct validity of the WVS and conclude that country level cultural values are appropriate proxies for the cultural values held by the employees of the firm. 
The WVS has several questions that should be relevant to the relation between a country's tournament structure and its cultural values. These questions measure the extent to which people see income inequality as desirable, hard work and competition as rewarding, and the workplace as hierarchical. In their study comparing CEO compensation across the United States, United Kingdom, and other European countries, Conyon and Murphy (2000) speculate that the differences could be due to higher cultural tolerance for income inequality in the United States that arises from differences in effort, talent, or risk-taking. That is, if individuals view working hard as beneficial, they could prefer a steeper tournament structure (greater income inequalities) as reward for their efforts. Based on this conjecture, we employ measures of a society's attitudes toward income inequality and fairness of income differences.

The two questions that measure national attitudes on income inequality can be summarized as i) whether it is fair for a person to be paid more when there are differences in efficiency and ii) whether income inequality is warranted to provide appropriate incentives. We refer to these as FAIR_INCOME_DIFFERENCES and INCOME_INEQUALITY. For FAIR_INCOME_DIFFERENCES, our measure is the percentage of positive responses - percentage negative responses +100 , implying, on a scale of 0 to 200, that 0 corresponds to a "Not Fair" perception and 200 corresponds to a "Fair" perception. Easterlin (1995) shows that in cultures where differences in pay due to differences in performance are more acceptable, when people compare themselves with relevant reference groups in assessing their income and consumption levels, they tend to be less satisfied with a given level of income when their neighbors earn more. This may provide incentives for them to work harder. In cultures where this is the norm, a tournament style of pay may work to provide additional motivation to work hard. Income inequality is measured as a country's average response to the survey on a scale of 1 to 10. Easterlin (2001) and Frey and Stutzer (2002a), (2002b) analyze income differentials and happiness and find that what matters for happiness is not income per se, but the gap between income and material aspirations. In cultures where income inequality is acceptable, a higher gap provides more incentives to work harder to acquire material possessions that make people happy. One can apply these findings to corporate tournaments: if income inequality is acceptable, then tournaments provide incentives to work harder.

We measure a country's attitudes toward hard work and competition using the outcomes of two other questions from the WVS. HARDWORK and COMPETITION are the average responses based on a scale of 1 to 10. HARDWORK measures whether the survey takers consider that hard work brings success. Granato, Inglehart, and Leblang (1996) study motivation and achievement and find that in cultures that value hard work, individual achievement provides substantial motivation to succeed. COMPETITION measures whether the survey takers consider competition to be good or harmful. Kaltenthaler, Ceccoli, and Gelleny (2008) find that in cultures that value competition, the belief exists that increasing economic competition results in increases in economic efficiency and a reduction in income inequality by encouraging individuals to work harder to overcome income inequality. In these same competitive societies, a higher tournament structure of pay, therefore, would lead to harder work and possibly improve firm performance. One can extrapolate 
from this insight that winning a tournament would provide incentives to excel. We have reversed the signs on HARDWORK and COMPETITION for ease of interpretation, that is, so that the tournament structure would be increasing in those variables. We provide a summary of the cultural, legal, and economic variables in Appendix A, the complete questions for the World Value Survey measures in Appendix B, and the magnitude of each country's measures in Appendix C.

If firms' tournament structures are related to cultural values as we hypothesize, a positive association should exist between the steepness of the tournament structure and each of the cultural variables. That is, the CEO_PAY_RATIO should increase in a society's willingness to accept power differentials, respect for individualism, perceptions that income differentials based on work differences are fair, that income inequality is desirable, that competition is good, and that hard work brings success.

\section{B. Country Economic and Institutional Characteristics and Cultural Values}

The tournament structure, the probability of winning the tournament, and the expected utility of such a win would be affected by a country's economic situation and both constrained by and reflected in the country's legal standards and cultural values. For example, as formulated in Lazear and Rosen (1981) and other models of tournaments, an important component of the tournament is the probability of winning (i.e., the random component). This random component would be expected to vary not only across companies, but also systematically across countries, as shared cultural values would result in differences in organizational structures and governance. For example, Schwartz (1999) maintains that "in societies where individual ambition and success are highly valued, the organisation of the economic and legal systems is likely to be competitive (e.g., capitalist markets and adversarial legal proceedings)," which is supportive of the argument that not only the existence of a tournament, but also the theoretical components that underlie the success of the tournament, would be tied to cultural values. We therefore expect the tournaments to provide different incentives in some cultures than others, and we test this by examining the relation between firm value and the interaction of culture and tournament. Similar to Doidge, Karolyi, and Stulz (2007), we control for economic conditions using GNP per capita for each year of the sample from the World Bank's World Development Indicators Database.

One would also expect differences in executive compensation, including differences in tournament structures, to be related to other country institutional factors. For example, given that higher investor protection is associated with more equity financing (La Porta, Lopez-de-Silanes, Shleifer, and Vishny (1997), (1998)), it should be particularly important to incentivize management to maximize shareholder value, and therefore, the tournament structure of compensation could be related to the level of investor protection in a country. ${ }^{21}$ Similarly, the legal

\footnotetext{
${ }^{21}$ As mentioned earlier, previous studies find differences in the level and composition of CEO compensation across countries, for example, Fernandes et al. (2013), although they argue that the differences are not substantial once one controls for international differences in corporate governance. Bryan et al. (2012) study CEO compensation of 256 ADR firms from 36 non-U.S. countries and find that firms in countries with stronger investor protection and with stronger rule of law have more equity
} 
environment may be important to the tournament structure. Thus, we use the Durnev and Kim (2005) measure, LEGAL, which is defined as the product of antidirector rights and rule of law, using the updated antidirector rights index from Spamann (2010).

We measure the distribution of income within a society using the country's GINI coefficient reported by the U.S. Central Intelligence Agency (CIA). A GINI coefficient of 0 implies perfect equality where all incomes are the same. A GINI coefficient of 1 (100 on the percentile scale) implies maximal inequality among values (e.g., where only one person receives all of the income).

The CEO tournament structures should vary across countries due to the variations in cultural values, economic climates, and investor protection regimes. Accordingly, we next test whether differences in culture influence the use of tournaments by firms, as well as the tournaments' effectiveness in improving performance.

\section{Empirical Tests of Cultural Values and CEO Tournament Structures}

We test our hypothesis that national cultural values influence CEO tournament structures by including the previously described cultural value characteristics as well as the country economic and legal characteristics. One potential concern with our specification is the extent of correlations between our country variables. We present a correlation matrix in Table 5 that shows substantial correlations among the country variables. There are high correlations between several of the cultural variables as well as the other country characteristics. In fact, all of the cultural variables are significantly correlated at the $10 \%$ level or better; $*$ denotes correlations in absolute magnitudes of 0.50 or greater. Thus, in adding the country characteristics (cultural and legal) to the compensation regressions, we first include each country variable separately.

\section{TABLE 5}

Correlations of Cultural, Economic, and Legal Attributes

Table 5 reports correlations of measures of culture from Hofstede (1980) and the WVS; a measure of a country's legal environment using the Durnev-Kim (2005) LEGAL variable, equal to the product of antidirector rights and rule of law, where the antidirector rights index is from Spamann (2010); and the economic variables from the CIA (GINI coefficient). The variables are described in Appendix A. * ${ }^{* *}$, and ${ }^{* * *}$ indicate significance at the $10 \%, 5 \%$, and $1 \%$ levels, respectively.

\begin{tabular}{|c|c|c|c|c|c|c|c|c|c|}
\hline Variables & 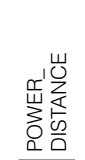 & 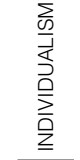 & 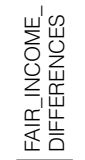 & 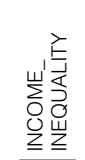 & 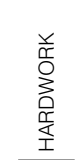 & $\begin{array}{l}z \\
\text { O } \\
\underline{E} \\
\underline{\underline{E}} \\
\sum_{0} \\
0\end{array}$ & $\begin{array}{l}\text { 志 } \\
\text { य }\end{array}$ & $\overline{\bar{N}}$ & 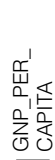 \\
\hline POWER_DISTANCE & 1.00 & & & & & & & & \\
\hline INDIVIDUALISM & -0.30 & 1.00 & & & & & & & \\
\hline FAIR_INCOME_DIFFERENCES & -0.07 & $0.60^{*}$ & 1.00 & & & & & & \\
\hline INCOME_INEQUALITY & -0.01 & $0.69^{*}$ & $0.57^{\star}$ & 1.00 & & & & & \\
\hline HARDWORK & -0.16 & -0.41 & -0.49 & -0.51 & 1.00 & & & & \\
\hline COMPETITION & 0.14 & -0.32 & $-0.61^{\star}$ & -0.49 & $0.73^{*}$ & 1.00 & & & \\
\hline LEGAL & -0.43 & 0.11 & -0.45 & -0.31 & $0.50^{*}$ & $0.50^{*}$ & 1.00 & & \\
\hline GINI & 0.29 & 0.34 & 0.45 & $0.60^{\star}$ & $-0.78^{\star}$ & $-0.59^{*}$ & $-0.71^{*}$ & 1.00 & \\
\hline GNP_PER_CAPITA & $-0.47^{\star}$ & $0.56^{\star}$ & $0.50^{\star}$ & 0.27 & 0.20 & 0.00 & 0.16 & -0.16 & 1.00 \\
\hline
\end{tabular}

compensation. In a study of 158 of the largest European firms in the year 2000, Muslu (2010) finds higher incentive compensation when agency costs are higher, but only in countries with higher investor protection. 
The results of the tournament compensation determinant regressions with cultural variables added are provided in Table 6 . We use the pay ratio as the CEO tournament measure in Panel A, where models 1-8 include POWER_DISTANCE, INDIVIDUALISM, FAIR_INCOME_DIFFERENCES, INCOME_INEQUALITY, HARDWORK, COMPETITION, LEGAL, and GINI, respectively. We also conduct comparable regressions in Panel B using the pay gap as the tournament measure. ${ }^{22}$ For each country's cultural measure, we subtract the sample mean in order to evaluate the influence of the cultural measure relative to the average. All regressions include standard errors clustered by firm in addition to industry and year fixed effects to correct for bias in standard errors (Petersen (2009)). In all six models, even after including the country characteristics, the differences between tournament structures in the U.S. and non-U.S. countries remain significant.

The results on the cultural variables indicate that greater ease with power differentials (POWER_DISTANCE), income differentials based on job performance (FAIR_INCOME_DIFFERENCES), and positive perceptions of the effects of competition (COMPETITION) are positively associated with steeper tournament structures. Moreover, each of these variables is economically significant. For instance, there is an $11 \%$ increase in the tournament for a 1-standard-deviation increase in POWER_DISTANCE. ${ }^{23}$ Since the average tournament measure (CEO_PAY_RATIO) is 1.94, this would increase it to 2.15, which equals an additional $\$ 102,000$ in pay for a non-U.S. CEO. The other cultural variables have insignificant coefficients. In regressions (7) and (8), we add the variables for the legal environment and GINI coefficient. Both are positive and significant. Tournaments are marginally larger in countries with better investor protection. The GINI coefficient suggests that steeper tournaments reflect greater income differentials in society in general. In fact, 1 standard deviation in the GINI coefficient results in a $6 \%$ increase in the pay slice. ${ }^{24}$

The regressions in Panel B of Table 6 with the pay gap tournament measure are similar, although coefficients increase in their significance levels. One notable difference in the results is that size is positively related to the pay gap. This follows because pay levels are correlated with firm size and, further, pay differences with pay levels; therefore, the gap measure is highly correlated with size. This result suggests that considering both tournament measures is important: the pay gap because it picks up the size of the prize, and the pay ratio because it ensures that we are not simply picking up size effects. ${ }^{25}$

Because of the correlations between the primary independent variables, we conduct a principal components factor analysis of the culture and legal variables

\footnotetext{
${ }^{22}$ Because of high correlations with some of the cultural variables, GNP per capita is orthogonalized against POWER_DISTANCE, INDIVIDUALISM, and FAIR_INCOME_DIFFERENCES when included in regressions with those variables.

${ }^{23}$ The standard deviation of POWER_DISTANCE is 17.52 , so $0.008 \times 17.52=11 \%$ increase in the pay slice for 1 standard deviation of POWER_ DISTANCE.

${ }^{24}$ When clustering standard errors by country, the results are similar except that LEGAL becomes insignificant.

${ }^{25}$ We also run the regressions in Panel A of Table 6 excluding U.S. companies from the analysis and find that the coefficients on POWER_DISTANCE, GINI, and COMPETITION remain significant.
} 
and include these factors in the model. The results are reported in Panel $\mathrm{C}$ of Table 6, where model 1 employs the pay ratio measure of tournament while model 2 employs the pay gap measure. The factor analysis shows that two factors are important. Factor 1 (F1), which is positive and significant, loads on FAIR_INCOME_DIFFERENCES, POWER_DISTANCE, and COMPETITION, while Factor 2 (F2) loads on HARDWORK, INDIVIDUALISM, LEGAL, and GINI.

\section{TABLE 6}

\section{CEO Tournaments and Cultural Values}

Panel A of Table 6 shows the multivariate estimation where the dependent variable is CEO_PAY_RATIO (total CEO compensation divided by the mean total compensation of the top 3 non-CEO executives), and Panel B shows the CEO PAY GAP (total CEO compensation minus the mean total compensation of the top 3 non-CEO executives). The independent variables are firm characteristics and cultural variables. The firm characteristics are U.S. firm (an indicator for whether the firm is headquartered in the United States), REVENUE, ASSETS, MARKET_VALUE, NET_INCOME, LEVERAGE (Total Debt/Assets), ROA (EBIT/Assets), CASH_RATIO (Cash/Assets), TOBINS Q (sum of MV of equity + BV of debt, divided by assets), \%_INSIDER (percentage of ownership held by insiders), and \%_INSTITUTION (percentage of ownership held by institutional investors). The cultural variables include POWER DISTANCE, INDIVIDUALISM, FAIR INCOME DIFFERENCES, INCOME INEQUALITY, HARDWORK, and COMPETITION, as well as LEGAL (Spamann $\times R O L)$ and the GINI coefficient. Cultural, legal, and economic variables are described in Appendix A. GNP_PER_CAPITA is orthogonalized against cultural attributes to which it is significantly correlated (power distance, individualism, and fair income differences). We use the log of GNP_PER_CAPITA in the estimations (log(GNP)). For each variable, the coefficient is reported with the $p$-value below in parentheses. Panels $A$ and $B$ report regressions with each of the cultural variables, separately. Panel $C$ reports regressions using the varimax rotated principal component factor analysis, where Factor 1 (F1) loads on FAIR_INCOME_DIFFERENCES, POWER_DISTANCE, and COMPETITION, while Factor 2 (F2) loads on HARDWORK, INDIVIDUALISM, LEGAL, and GINI. We control for robust standard errors clustered by firm as well as industry and year fixed effects. *, ${ }^{* *}$, and ${ }^{* * *}$ indicate significance at the $10 \%, 5 \%$, and $1 \%$ levels, respectively.

\begin{tabular}{|c|c|c|c|c|c|c|c|c|}
\hline Variable & 1 & 2 & 3 & 4 & 5 & 6 & 7 & 8 \\
\hline \multicolumn{9}{|c|}{ Panel A. Individual Cultural Measures Using CEO_PAY_RATIO } \\
\hline U.S. firm & $\begin{array}{l}0.309^{\star \star \star} \\
(0.00)\end{array}$ & $\begin{array}{l}0.313^{\star \star \star *} \\
(0.00)\end{array}$ & $\begin{array}{l}0.185^{\star \star \star \star} \\
(0.00)\end{array}$ & $\begin{array}{l}0.311^{\star \star \star *} \\
(0.00)\end{array}$ & $\begin{array}{l}0.295^{* \star *} \\
(0.00)\end{array}$ & $\begin{array}{l}0.321^{\star \star \star} \\
(0.00)\end{array}$ & $\begin{array}{l}0.414^{* \star *} \\
(0.00)\end{array}$ & $\begin{array}{l}0.480^{\star \star \star} . \\
(0.00)\end{array}$ \\
\hline $\log ($ REVENUE) & $\begin{array}{l}-0.017^{\star \star} \\
(0.02)\end{array}$ & $\begin{array}{c}-0.014^{*} \\
(0.07)\end{array}$ & $\begin{array}{c}-0.014^{*} \\
(0.07)\end{array}$ & $\begin{array}{c}-0.014^{*} \\
(0.06)\end{array}$ & $\begin{array}{l}-0.014^{*} \\
(0.07)\end{array}$ & $\begin{array}{l}-0.015^{*} \\
(0.05)\end{array}$ & $\begin{array}{c}-0.012 \\
(0.11)\end{array}$ & $\begin{array}{l}-0.015^{*} \\
(0.05)\end{array}$ \\
\hline LEVERAGE & $\begin{array}{c}0.083 \\
(0.23)\end{array}$ & $\begin{array}{l}0.086 \\
(0.22)\end{array}$ & $\begin{array}{c}0.083 \\
(0.23)\end{array}$ & $\begin{array}{l}0.085 \\
(0.22)\end{array}$ & $\begin{array}{c}0.086 \\
(0.21)\end{array}$ & $\begin{array}{c}0.085 \\
(0.22)\end{array}$ & $\begin{array}{c}0.087 \\
(0.21)\end{array}$ & $\begin{array}{c}0.083 \\
(0.23)\end{array}$ \\
\hline CASH_RATIO & $\begin{array}{c}0.012 \\
(0.90)\end{array}$ & $\begin{array}{c}0.01 \\
(0.92)\end{array}$ & $\begin{array}{c}0.014 \\
(0.89)\end{array}$ & $\begin{array}{l}0.01 \\
(0.92)\end{array}$ & $\begin{array}{c}0.009 \\
(0.93)\end{array}$ & $\begin{array}{c}0.011 \\
(0.91)\end{array}$ & $\begin{array}{c}0.006 \\
(0.95)\end{array}$ & $\begin{array}{c}0.012 \\
(0.90)\end{array}$ \\
\hline $\log (G N P)$ & $\begin{array}{c}-0.008 \\
(0.88)\end{array}$ & $\begin{array}{l}-0.087^{\star} \\
(0.07)\end{array}$ & $\begin{array}{l}-0.120^{\star \star \star \star} \\
(0.01)\end{array}$ & $\begin{array}{c}-0.062 \\
(0.16)\end{array}$ & $\begin{array}{c}-0.034 \\
(0.56)\end{array}$ & $\begin{array}{r}-0.057 \\
(0.23)\end{array}$ & $\begin{array}{c}-0.116^{\star \star} \\
(0.03)\end{array}$ & $\begin{array}{l}-0.161^{\star \star *} \\
(0.03)\end{array}$ \\
\hline \%_INSIDER & $\begin{array}{r}0.001 \\
(0.86)\end{array}$ & $\begin{array}{r}0.001 \\
(0.96)\end{array}$ & $\begin{array}{r}0.001 \\
(0.83)\end{array}$ & $\begin{array}{l}0.001 \\
(0.97)\end{array}$ & $\begin{array}{r}0.001 \\
(0.98)\end{array}$ & $\begin{array}{r}0.001 \\
(0.97)\end{array}$ & $\begin{array}{l}0.001 \\
(0.92)\end{array}$ & $\begin{array}{c}0.001 \\
(0.89)\end{array}$ \\
\hline \%_INSTITUTION & $\begin{array}{l}0.004^{\star \star \star *} \\
(0.00)\end{array}$ & $\begin{array}{l}0.004^{\star \star \star \star} \\
(0.00)\end{array}$ & $\begin{array}{l}0.004^{\star \star \star *} \\
(0.00)\end{array}$ & $\begin{array}{l}0.004^{\star \star \star \star} \\
(0.00)\end{array}$ & $\begin{array}{l}0.004^{* * *} \\
(0.00)\end{array}$ & $\begin{array}{l}0.004^{* * *} \\
(0.00)\end{array}$ & $\begin{array}{l}0.004^{\star \star \star \star} \\
(0.00)\end{array}$ & $\begin{array}{l}0.004^{\star \star \star} . \\
(0.00)\end{array}$ \\
\hline POWER_DISTANCE & $\begin{array}{l}0.006^{\star \star} \\
(0.03)\end{array}$ & & & & & & & \\
\hline INDIVIDUALISM & & $\begin{array}{c}0.001 \\
(0.66)\end{array}$ & & & & & & \\
\hline $\begin{array}{l}\text { FAIR_INCOME } \\
\text { DIFFERENCES }\end{array}$ & & & $\begin{array}{l}0.005^{\star \star \star *} \\
(0.00)\end{array}$ & & & & & \\
\hline INCOME_INEQUALITY & & & & $\begin{array}{l}0.032 \\
(0.48)\end{array}$ & & & & \\
\hline HARDWORK & & & & & $\begin{array}{c}0.045 \\
(0.41)\end{array}$ & & & \\
\hline COMPETITION & & & & & & $\begin{array}{l}0.021^{\star} \\
(0.07)\end{array}$ & & \\
\hline LEGAL & & & & & & & $\begin{array}{l}0.009^{*} \\
(0.08)\end{array}$ & \\
\hline GINI & & & & & & & & $\begin{array}{l}0.010^{\star \star} \\
(0.03)\end{array}$ \\
\hline Constant & $\begin{array}{l}1.225^{\star \star \star *} \\
(0.00)\end{array}$ & $\begin{array}{l}1.176^{\star \star \star *} \\
(0.00)\end{array}$ & $\begin{array}{l}1.276^{\star \star \star \star} \\
(0.00)\end{array}$ & $\begin{array}{l}1.855^{\star \star \star *} \\
(0.00)\end{array}$ & $\begin{array}{l}1.558^{\star \star} \\
(0.01)\end{array}$ & $\begin{array}{l}1.790^{\star * \star} \\
(0.00)\end{array}$ & $\begin{array}{l}2.341^{\star \star \star \star} \\
(0.00)\end{array}$ & $\begin{array}{l}3.208^{*{ }^{* *}} \\
(0.00)\end{array}$ \\
\hline $\begin{array}{l}\text { No. of obs. } \\
\text { Adj. } R^{2}\end{array}$ & $\begin{array}{r}20,624 \\
0.050\end{array}$ & $\begin{array}{r}20,624 \\
0.050\end{array}$ & $\begin{array}{r}20,624 \\
0.050\end{array}$ & $\begin{array}{r}20,624 \\
0.050\end{array}$ & $\begin{array}{r}20,624 \\
0.050\end{array}$ & $\begin{array}{r}20,624 \\
0.050\end{array}$ & $\begin{array}{r}20,624 \\
0.050\end{array}$ & $\begin{array}{r}20,624 \\
0.050\end{array}$ \\
\hline
\end{tabular}


TABLE 6 (continued)

CEO Tournaments and Cultural Values

\begin{tabular}{|c|c|c|c|c|c|c|c|c|}
\hline Variable & 1 & 2 & 3 & 4 & 5 & 6 & 7 & 8 \\
\hline \multicolumn{9}{|c|}{ Panel B. Individual Cultural Measures Using CEO_PAY_GAP } \\
\hline U.S. firm & $\begin{array}{l}0.783^{\star \star \star} \\
(0.00)\end{array}$ & $\begin{array}{l}0.625^{* \star \star} \\
(0.00)\end{array}$ & $\begin{array}{l}0.353^{k * *} \\
(0.00)\end{array}$ & $\begin{array}{l}0.611^{* * * *} \\
(0.00)\end{array}$ & 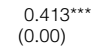 & $\begin{array}{l}0.558^{\star \star \star} \\
(0.00)\end{array}$ & $\begin{array}{l}1.054^{\star \star \star \star} \\
(0.00)\end{array}$ & $\begin{array}{l}0.987^{* \star *} \\
(0.00)\end{array}$ \\
\hline $\log ($ REVENUE) & $\begin{array}{l}0.245^{\star \star \star} \\
(0.00)\end{array}$ & $\begin{array}{l}0.251^{\star \star \star} \\
(0.00)\end{array}$ & $\begin{array}{l}0.245^{\star \star \star \star} \\
(0.00)\end{array}$ & $\begin{array}{l}0.246^{\star \star *} \\
(0.00)\end{array}$ & $\begin{array}{l}0.252^{\star \star *} \\
(0.00)\end{array}$ & $\begin{array}{l}0.246^{\star \star \star} \\
(0.00)\end{array}$ & $\begin{array}{l}0.252^{\star \star \star} \\
(0.00)\end{array}$ & $\begin{array}{l}0.242^{\star \star \star} \\
(0.00)\end{array}$ \\
\hline LEVERAGE & $\begin{array}{c}0.147 \\
(0.15)\end{array}$ & $\begin{array}{l}0.147 \\
(0.15)\end{array}$ & $\begin{array}{c}0.139 \\
(0.17)\end{array}$ & $\begin{array}{c}0.144 \\
(0.16)\end{array}$ & $\begin{array}{c}0.149 \\
(0.14)\end{array}$ & $\begin{array}{c}0.146 \\
(0.15)\end{array}$ & $\begin{array}{r}0.151 \\
(0.14)\end{array}$ & $\begin{array}{r}0.140 \\
(0.17)\end{array}$ \\
\hline CASH_RATIO & $\begin{array}{l}0.554^{\star \star \star} \\
(0.00)\end{array}$ & $\begin{array}{l}0.563^{* \star \star \star} \\
(0.00)\end{array}$ & $\begin{array}{l}0.546^{\star \star \star *} \\
(0.00)\end{array}$ & $\begin{array}{l}0.561^{* * * *} \\
(0.00)\end{array}$ & $\begin{array}{l}0.578^{* * *} \\
(0.00)\end{array}$ & $\begin{array}{l}0.555^{\star \star \star} \\
(0.00)\end{array}$ & $\begin{array}{l}0.574^{* \star *} \\
(0.00)\end{array}$ & $\begin{array}{l}0.552^{\star \star \star *} \\
(0.00)\end{array}$ \\
\hline $\log (G N P)$ & $\begin{array}{c}-0.058 \\
(0.30)\end{array}$ & $\begin{array}{l}0.109^{\star} \\
(0.07)\end{array}$ & $\begin{array}{l}0.118^{\star \star \star *} \\
(0.00)\end{array}$ & $\begin{array}{c}0.034 \\
(0.33)\end{array}$ & $\begin{array}{l}0.275^{\text {***}} \\
(0.00)\end{array}$ & $\begin{array}{l}0.121^{* *} \\
(0.04)\end{array}$ & $\begin{array}{l}0.172^{\star \star} \\
(0.01)\end{array}$ & $\begin{array}{l}0.130^{\star * *} \\
(0.02)\end{array}$ \\
\hline$\%$ INSIDER & $\begin{array}{l}-0.004^{\star \star \star} \\
(0.00)\end{array}$ & $\begin{array}{l}-0.004^{\star \star \star \star} \\
(0.00)\end{array}$ & $\begin{array}{l}-0.005^{\text {*k*}} \\
(0.00)\end{array}$ & $\begin{array}{l}-0.004^{\star * * *} \\
(0.00)\end{array}$ & $\begin{array}{l}-0.004^{* * *} \\
(0.00)\end{array}$ & $\begin{array}{l}-0.004^{\star \star \star \star} \\
(0.00)\end{array}$ & $\begin{array}{l}-0.004^{* \star *} \\
(0.00)\end{array}$ & $\begin{array}{l}-0.005^{\star \star \star} \\
(0.00)\end{array}$ \\
\hline \%_INSTITUTION & $\begin{array}{l}0.009^{\star * *} \\
(0.00)\end{array}$ & $\begin{array}{l}0.008^{\star \star \star} \\
(0.00)\end{array}$ & $\begin{array}{l}0.009^{\star * *} \\
(0.00)\end{array}$ & $\begin{array}{l}0.009^{\kappa * k} \\
(0.00)\end{array}$ & $\begin{array}{l}0.008^{\star * \star *} \\
(0.00)\end{array}$ & $\begin{array}{l}0.009^{\star \star \star} \\
(0.00)\end{array}$ & $\begin{array}{l}0.008^{\star \star \star *} \\
(0.00)\end{array}$ & $\begin{array}{l}0.009^{* * *} \\
(0.00)\end{array}$ \\
\hline POWER_DISTANCE & $\begin{array}{l}0.008^{\star \star} \\
(0.03)\end{array}$ & & & & & & & \\
\hline INDIVIDUALISM & & $\begin{array}{l}0.015^{\star \star \star} \\
(0.00)\end{array}$ & & & & & & \\
\hline $\begin{array}{l}\text { FAIR_INCOME_- } \\
\text { DIFFERENCES }\end{array}$ & & & $\begin{array}{l}0.015^{\star \star \star \star} \\
(0.00)\end{array}$ & & & & & \\
\hline INCOME_INEQUALITY & & & & $\begin{array}{l}0.189^{\kappa * k} \\
(0.01)\end{array}$ & & & & \\
\hline HARDWORK & & & & & $\begin{array}{l}0.388^{* * *} \\
(0.00)\end{array}$ & & & \\
\hline COMPETITION & & & & & & $\begin{array}{l}0.328^{\star \star} \\
(0.01)\end{array}$ & & \\
\hline LEGAL & & & & & & & $\begin{array}{l}0.034^{\star \star \star *} \\
(0.00)\end{array}$ & \\
\hline GINI & & & & & & & & $\begin{array}{l}0.017^{\star \star \star} \\
(0.00)\end{array}$ \\
\hline Constant & $\begin{array}{l}-1.580^{\star * \star *} \\
(0.00)\end{array}$ & $\begin{array}{l}-1.565^{* * \star} \\
(0.00)\end{array}$ & $\begin{array}{c}-1.274^{\text {*k* }} \\
(0.00)\end{array}$ & $\begin{array}{l}-1.795^{\text {****}} \\
(0.00)\end{array}$ & $\begin{array}{l}-4.333^{\star * * *} \\
(0.00)\end{array}$ & $\begin{array}{l}-2.694^{\star * * *} \\
(0.00)\end{array}$ & $\begin{array}{c}0.054 \\
(0.94)\end{array}$ & $\begin{array}{c}0.399 \\
(0.58)\end{array}$ \\
\hline $\begin{array}{l}\text { No. of obs. } \\
\text { Adj. } R^{2}\end{array}$ & $\begin{array}{r}20,624 \\
0.182\end{array}$ & $\begin{array}{r}20,624 \\
0.183\end{array}$ & $\begin{array}{r}20,624 \\
0.184\end{array}$ & $\begin{array}{r}20,624 \\
0.182\end{array}$ & $\begin{array}{r}20,624 \\
0.183\end{array}$ & $\begin{array}{r}20,624 \\
0.182\end{array}$ & $\begin{array}{r}20,624 \\
0.183\end{array}$ & $\begin{array}{r}20,624 \\
0.182\end{array}$ \\
\hline \multicolumn{5}{|c|}{ CEO_PAY_RATIO } & & & \multicolumn{2}{|c|}{ CEO_PAY_GAP } \\
\hline Variable & & & \multicolumn{2}{|c|}{1} & & & \multicolumn{2}{|c|}{2} \\
\hline \multicolumn{9}{|c|}{ Panel C. Joint Estimations of Culture Using Factor Analysis } \\
\hline U.S. firm & & & \multicolumn{2}{|c|}{$\begin{array}{c}0.201 \\
(0.28)\end{array}$} & & & \multicolumn{2}{|c|}{$\begin{array}{c}0.076 \\
(0.76)\end{array}$} \\
\hline $\log ($ REVENUE) & & & \multicolumn{2}{|c|}{$\begin{array}{c}-0.014^{*} \\
(0.07)\end{array}$} & & & \multicolumn{2}{|c|}{$\begin{array}{l}0.257^{\star * *} \\
(0.00)\end{array}$} \\
\hline LEVERAGE & & & \multicolumn{2}{|c|}{$\begin{array}{c}0.086 \\
(0.22)\end{array}$} & & & \multicolumn{2}{|c|}{$\begin{array}{c}0.149 \\
(0.14)\end{array}$} \\
\hline CASH_RATIO & & & \multicolumn{2}{|c|}{$\begin{array}{r}0.010 \\
(0.92)\end{array}$} & & & \multicolumn{2}{|c|}{$\begin{array}{l}0.570^{* * *} \\
(0.00)\end{array}$} \\
\hline $\log (G N P)$ & & & \multicolumn{2}{|c|}{$\begin{array}{c}-0.020 \\
(0.85)\end{array}$} & & & \multicolumn{2}{|c|}{$\begin{array}{c}0.060 \\
(0.69)\end{array}$} \\
\hline$\%$ INSIDER & & & \multicolumn{2}{|c|}{$\begin{array}{r}0.001 \\
(0.97)\end{array}$} & & & \multicolumn{2}{|c|}{$\begin{array}{l}-0.004^{\star * *} \\
(0.00)\end{array}$} \\
\hline \%_INSTITUTIONAL & & & \multicolumn{2}{|c|}{$\begin{array}{l}0.004^{* * *} \\
(0.00)\end{array}$} & & & \multicolumn{2}{|c|}{$\begin{array}{l}0.008^{\text {***}} \\
(0.00)\end{array}$} \\
\hline $\mathrm{F} 1$ & & & \multicolumn{2}{|c|}{$\begin{array}{l}0.060^{\text {** }} \\
(0.04)\end{array}$} & & & \multicolumn{2}{|c|}{$\begin{array}{l}0.333^{* * *} \\
(0.00)\end{array}$} \\
\hline F2 & & & \multicolumn{2}{|c|}{$\begin{array}{r}0.005 \\
(0.87)\end{array}$} & & & \multicolumn{2}{|c|}{$\begin{array}{l}0.077^{\star} \\
(0.10)\end{array}$} \\
\hline Constant & & & \multicolumn{2}{|c|}{$\begin{array}{c}1.475 \\
(0.16)\end{array}$} & & & \multicolumn{2}{|c|}{$\begin{array}{r}-1.817 \\
(0.23)\end{array}$} \\
\hline $\begin{array}{l}\text { No. of obs. } \\
\text { Adj. } R^{2}\end{array}$ & & & \multicolumn{2}{|c|}{$\begin{array}{r}20,624 \\
0.050\end{array}$} & & & \multicolumn{2}{|c|}{$\begin{array}{r}20,624 \\
0.184\end{array}$} \\
\hline
\end{tabular}


It is also notable that in these models, which capture the explanatory power from multiple cultural variables, the U.S. indicator becomes insignificant. The implication is that cultural characteristics explain much of the previously unexplained differences in tournaments between the United States and other countries.

In unreported tests, we use a full sample of firms not conditioning on 100 observations per country. We obtain similar results in that POWER_DISTANCE, COMPETITION, and FAIR_INCOME_DIFFERENCES help to explain the tournament structure; however, the LEGAL measure and GINI coefficient are not significant.

\section{CEO Tournaments and Firm Value}

According to the theories on tournaments (e.g., Lazear and Rosen (1981)), the tournament structure results in better managerial performance and greater firm value, which empirically suggests a positive relationship between executive pay disparity and firm valuation. Lazear and Rosen (1981), Green and Stokey (1983), and Rosen (1986) show that the effectiveness of a tournament depends on the relative performance of the participants as well as the motivation provided by the size of the prize. However, as discussed earlier, the degree to which pay disparities and other characteristics of a tournament would be accepted in a society should also be factors in the effectiveness of the tournament incentives. From Table 6, we have shown a relation between cultural values and tournament structures. In this section, we test whether the effectiveness of the tournament structures varies across countries by examining whether the relation between Tobin's $q$ and tournament structure varies according to cultural characteristics.

The relationship between firm value and tournament structure has been tested previously within a few individual countries (the United States, the United Kingdom, and Denmark) with mixed results. Two studies (Rajgopal and Srinivasan (2006) using U.S. data and Conyon et al. (2001) using U.K. data) conclude that there is no evidence that tournament pay is significantly related to firm performance. On the other hand, several studies find evidence in support of the tournament theory. For example, Lee et al. (2008) and Kale et al. (2009) conclude that a positive relation exists between CEO tournaments and firm performance for U.S. firms. ${ }^{26}$

We test whether the tournament structure is related to performance in our international sample by regressing a measure of firm value (Tobin's $q$ ) on our measures of the structure. First, given that Table 6 shows that culture influences tournament structures, we examine whether the relation between $q$ and tournament structure is heightened in the presence of cultural characteristics. For instance, if competition and power distance are more acceptable in a culture, then their greater acceptance and steeper tournament structures could react together to enhance firm value. Alternatively, the fact that a particular culture prefers more teamwork may make a smaller tournament as effective as a larger tournament in a country that prefers more competition.

\footnotetext{
${ }^{26}$ In addition, Eriksson (1999) (for Danish companies) and Audas, Barmby, and Treble (2004) (for a single British employer) find support for the predictions of tournament theory that executive effort is positively related to the spread in compensation.
} 
Table 7 reports results of regressions of firm value on the interaction of tournament and measures of culture. We include country indicators in the regressions, rather than culture by itself, since many country level factors besides culture affect firm value. Because country subsumes culture, we exclude the country cultural values as stand-alone variables. All of the regressions include industry (FamaFrench 12, http://mba.tuck.dartmouth.edu/pages/faculty/ken.french/Data_Library /det_12_ind_port.html) and year controls. Standard errors are clustered by firm. Model 1 uses the pay ratio as the measure of CEO tournament, while model 2 uses the pay gap. Because the cultural variables are highly correlated in model 2 , we include the two factors from the principal component factor analysis of cultural variables (where we use varimax rotation). We find that F1, which loads primarily on COMPETITION, POWER_DISTANCE, and FAIR_INCOME_DIFFERENCES, is the only significant interaction. We interpret this result to imply that in countries in which the commonalities in these cultural measures are more acceptable, a higher tournament structure results in better performance.

\section{TABLE 7}

Tournament Structure, Firm Value, and Culture

Table 7 reports the multivariate estimation where the dependent variable, Tobin's $q$, is regressed on the interaction of tournament and measures of culture. The independent variables are all lagged 1 year. The CEO tournament measure is CEO PAY RATIO (total compensation to the CEO/mean total compensation to the other top executives) in models 1 and 3 and CEO_PAY_GAP (the difference in total compensation between the CEO and the median of other executives) in models 2 and 4 . The regressions also include firm characteristics and cultural variables. The firm characteristics are REVENUE, ASSETS, MARKET_VALUE, NET_INCOME, LEVERAGE (Total Debt/Assets), ROA (EBIT/Assets), CASH_RATIO (Cash/Assets), TOBINS_Q (sum of MV of equity + BV of debt, divided by assets), \%_INSIDER (percentage of ownership held by insiders), and \%_INSTITUTION (percentage of ownership held by institutional investors). Because the cultural variables are highly correlated, we include the 2 factors from the principal component factor analysis of cultural variables (where we use varimax rotation). F1 loads primarily on COMPETITION, POWER_DISTANCE, and FAIR_INCOME_DIFFERENCES, while F2 loads on HARDWORK, INDIVIDUALISM, LEGAL, and GINI. Models 1 and 2 use an OLSQ. Models 3 and 4 take into account these possible endogenous relationships, and we conduct a 2SLS estimation. As instruments, we use the median values of both tournament variables for firms in the same industry and in the same size quartile as the firm. We do not report the first stage. $p$-values are reported in parentheses. * ${ }^{* *}$, and ${ }^{* \star *}$ indicate significance at the $10 \%, 5 \%$, and $1 \%$ levels, respectively. We control for robust standard errors clustered by firm, as well as country, industry, and year fixed effects.

\begin{tabular}{|c|c|c|c|c|}
\hline \multirow{3}{*}{ Variable } & \multicolumn{2}{|c|}{ OLSQ } & \multicolumn{2}{|c|}{ 2-Stage } \\
\hline & Pay Ratio & Pay Gap & Pay Ratio & Pay Gap \\
\hline & 1 & 2 & 3 & 4 \\
\hline CEO_TOURNAMENT_MEASURE & $\begin{array}{c}0.029 \\
(0.40)\end{array}$ & $\begin{array}{l}0.074^{\star \star *} \\
(0.00)\end{array}$ & $\begin{array}{c}0.113 \\
(0.49)\end{array}$ & $\begin{array}{c}0.005 \\
(0.94)\end{array}$ \\
\hline $\log (R E V E N U E)$ & $\begin{array}{l}-0.149^{\text {** }} \\
(0.00)\end{array}$ & $\begin{array}{l}-0.169^{\star * \star} \\
(0.00)\end{array}$ & $\begin{array}{l}-0.150^{\star \star \star} \\
(0.00)\end{array}$ & $\begin{array}{l}-0.151^{\text {}} \\
(0.00)\end{array}$ \\
\hline LEVERAGE & $\begin{array}{l}0.460^{\star} \\
(0.05)\end{array}$ & $\begin{array}{l}0.453^{*} \\
(0.05)\end{array}$ & $\begin{array}{l}0.460^{* \star} \\
(0.05)\end{array}$ & $\begin{array}{l}0.459^{\star} \\
(0.05)\end{array}$ \\
\hline CASH_RATIO & $\begin{array}{l}5.410^{\star \star \star} \\
(0.00)\end{array}$ & $\begin{array}{l}5.374^{\star \star \star} \\
(0.00)\end{array}$ & $\begin{array}{l}5.410^{* * *} \\
(0.00)\end{array}$ & $\begin{array}{l}5.415^{\text {} \star \star \star ~} \\
(0.00)\end{array}$ \\
\hline $\log (G N P)$ & $\begin{array}{l}2.805^{\star \star \star} \\
(0.00)\end{array}$ & $\begin{array}{l}2.939^{\star \star \star} \\
(0.00)\end{array}$ & $\begin{array}{l}2.760^{* * *} \\
(0.00)\end{array}$ & $\begin{array}{l}2.600^{\star \star \star} \\
(0.00)\end{array}$ \\
\hline$\%$ \%INSIDER & $\begin{array}{c}-0.002 \\
(0.36)\end{array}$ & $\begin{array}{c}-0.002 \\
(0.43)\end{array}$ & $\begin{array}{c}-0.002 \\
(0.35)\end{array}$ & $\begin{array}{c}-0.002 \\
(0.34)\end{array}$ \\
\hline \%_INSTITUTION & $\begin{array}{c}0.001 \\
(0.51)\end{array}$ & $\begin{array}{c}0.000 \\
(0.74)\end{array}$ & $\begin{array}{c}0.001 \\
(0.49)\end{array}$ & $\begin{array}{c}0.001 \\
(0.47)\end{array}$ \\
\hline CEO_TOURNAMENT $\times$ F1 & $\begin{array}{l}0.032^{\star \star} \\
(0.02)\end{array}$ & $\begin{array}{l}0.017^{*} \\
(0.08)\end{array}$ & $\begin{array}{l}0.043^{*} \\
(0.06)\end{array}$ & $\begin{array}{l}0.109^{\star \star} \\
(0.02)\end{array}$ \\
\hline CEO_TOURNAMENT $\times$ F2 & $\begin{array}{c}0.046 \\
(0.11)\end{array}$ & $\begin{array}{c}0.036 \\
(0.23)\end{array}$ & $\begin{array}{l}0.103^{*} \\
(0.09)\end{array}$ & $\begin{array}{l}0.086^{\star} \\
(0.06)\end{array}$ \\
\hline Constant & $\begin{array}{l}36.849^{\text {** }} \\
(0.00)\end{array}$ & $\begin{array}{l}36.228^{\star * *} \\
(0.00)\end{array}$ & $\begin{array}{l}36.849^{\star \star \star} \\
(0.00)\end{array}$ & $\begin{array}{l}36.228^{\star \star \star} \\
(0.00)\end{array}$ \\
\hline $\begin{array}{l}\text { No. of obs. } \\
\text { Adj. } R^{2}\end{array}$ & $\begin{array}{r}20,467 \\
0.086\end{array}$ & $\begin{array}{r}20,467 \\
0.086\end{array}$ & $\begin{array}{r}20,467 \\
0.086\end{array}$ & $\begin{array}{r}20,467 \\
0.086\end{array}$ \\
\hline
\end{tabular}


An important concern about the model specification in Table 7 is the degree of endogeneity in the relationships. As pointed out by Kale et al. (2009), tournament incentives, performance-based incentives, and firm performance are potentially endogenously determined. Further, culture can affect both the tournament structure and the executive's attitudes toward effort, both of which affect firm value. To take into account these possible endogenous relationships, we conduct a 2-stage least-squares (2SLS) estimation. As instruments, we use the median values of both tournament variables for firms in the same country, industry (Fama-French 12 industries), and year as the firm. ${ }^{27}$ The logic is that the industry tournament structure is unique to each industry and, therefore, can serve as an exogenous regressor in the first stage. The results of the second stage are reported in Table 7, models 4 and 5, for the ratio and pay gap measures, respectively. The results continue to indicate that the interaction of culture and larger tournament incentives affect firm value. In unreported results, we estimate the same analysis using ROA and buy and hold returns as measures of performance and obtain qualitatively similar results.

These results suggest that the relation between $q$ and tournaments is heightened in the presence of cultural characteristics relating to competition, power distance, and perceptions of income differences. However, it is possible that in some cultures, a smaller tournament may be more effective in promoting better performance. A smaller tournament could potentially provide the same motivation in a country that prefers teamwork as a large tournament would in a winner-take-all competitive culture. To test whether this conjecture holds, we segment our sample by country. In doing so, we can determine whether in some countries a less steep tournament will increase firm value more.

We estimate our 2SLS model for each of the countries in our sample separately. The second-stage results are presented in Panels A and B of Table 8. In Panel A, we use CEO_PAY_GAP as our tournament measure and find differences across the countries as expected. In particular, larger tournaments are more positively associated with firm value in some of the countries that have common law origins: the United Kingdom, the United States, and Australia. Larger tournaments are also positively, though less strongly, associated with firm value (at the $10 \%$ level) in Germany, Hong Kong, India, and Switzerland. Interestingly, larger pay gaps in Canada and the Netherlands are negatively associated with firm value. While we do not have a strong explanation for this negative relation, in some cases, CEO pay is less than or nominally different than non-CEO pay in the Netherlands, and there is more variance in the tournament structure among Canadian firms than in other countries. Culture may also play a role in these results, since the Netherlands does not believe that pay differences due to hard work deserve more pay (low HARDWORK score) and Canada scores lower than the United States for INDIVIDUALISM.

In Panel B of Table 8, we add the square of the tournament pay gap as an additional independent variable to capture any nonlinearities in the relationship. Our results indicate that pay differences between the CEO and the rest of the top management team are associated with higher firm value. However, even in

\footnotetext{
${ }^{27}$ This approach was also used in Kale et al. (2009).
} 


\section{TABLE 8}

\section{Firm Value and Tournament Structure within Country}

Table 8 reports the multivariate estimation of firm value measured by TOBINS_Q (sum of MV of equity + BV of debt, divided by assets) against tournament structure in each country where CEO tournament is measured by the CEO_PAY_GAP (total CEO compensation minus the mean total compensation of the top 3 non-CEO executives). The other independent variables are the firm characteristics REVENUE, LEVERAGE (Total Debt/Assets), CASH_RATIO (Cash/Assets), \%_INSIDER (percentage of ownership held by insiders), and \%_INSTITUTION (percentage of ownership held by institutional investors), all lagged by 1 year. Panel A provides the regression with CEO_PAY_GAP and the firm characteristics. Panel B adds the squared value of CEO_PAY_GAP to the regression. $p$-values are below in parentheses. ${ }^{*}$, ${ }^{* *}$, and ${ }_{* * *}$ indicate significance at the $10 \%, 5 \%$, and $1 \%$ levels, respectively. We control for robust standard errors clustered by firm as well as industry and year fixed effects.

\begin{tabular}{|c|c|c|c|c|c|c|c|c|c|c|c|c|c|c|}
\hline \multirow{3}{*}{ Variable } & \multicolumn{14}{|c|}{ Dependent Variable: TOBINS_Q } \\
\hline & Australia & Canada & China & France & Germany & $\begin{array}{l}\text { Hong } \\
\text { Kong }\end{array}$ & India & Netherlands & Norway & $\begin{array}{l}\text { South } \\
\text { Africa }\end{array}$ & Sweden & Switzerland & $\begin{array}{l}\text { United } \\
\text { Kingdom }\end{array}$ & $\begin{array}{l}\text { United } \\
\text { States }\end{array}$ \\
\hline & 1 & 2 & 3 & 4 & 5 & 6 & 7 & 8 & 9 & 10 & 11 & 12 & 13 & 14 \\
\hline \multicolumn{15}{|c|}{ Panel A. Firm Value and CEO_PAY_GAP } \\
\hline CEO_PAY_GAP & $\begin{array}{l}3.125^{\star \star *} \\
(0.00)\end{array}$ & $\begin{array}{c}-0.340^{*} \\
(0.08)\end{array}$ & $\begin{array}{c}0.130 \\
(0.87)\end{array}$ & $\begin{array}{l}0.059^{*} \\
(0.07)\end{array}$ & $\begin{array}{l}0.104^{*} \\
(0.09)\end{array}$ & $\begin{array}{l}1.257^{\star} \\
(0.06)\end{array}$ & $\begin{array}{l}6.674^{\star} \\
(0.07)\end{array}$ & $\begin{array}{l}-0.434^{\star \star *} \\
(0.01)\end{array}$ & $\begin{array}{c}-0.382 \\
(0.30)\end{array}$ & $\begin{array}{l}0.775^{\star * *} \\
(0.00)\end{array}$ & $\begin{array}{c}0.236 \\
(0.26)\end{array}$ & $\begin{array}{l}0.082^{*} \\
(0.08)\end{array}$ & $\begin{array}{l}0.402^{\star \star} \\
(0.04)\end{array}$ & $\begin{array}{l}0.051^{\star \star \star} \\
(0.00)\end{array}$ \\
\hline $\log ($ REVENUE) & $\begin{array}{l}-0.289^{* * *} \\
(0.00)\end{array}$ & $\begin{array}{c}-0.018 \\
(0.48)\end{array}$ & $\begin{array}{c}0.041 \\
(0.72)\end{array}$ & $\begin{array}{l}0.038^{* *} \\
(0.02)\end{array}$ & $\begin{array}{c}-0.004 \\
(0.81)\end{array}$ & $\begin{array}{c}0.069 \\
(0.18)\end{array}$ & $\begin{array}{l}0.835^{\star} \\
(0.06)\end{array}$ & $\begin{array}{c}-0.351^{* *} \\
(0.04)\end{array}$ & $\begin{array}{l}0.079^{*} \\
(0.08)\end{array}$ & $\begin{array}{c}0.080 \\
(0.62)\end{array}$ & $\begin{array}{c}-0.256^{*} \\
(0.09)\end{array}$ & $\begin{array}{l}0.125^{\star \star \star} \\
(0.00)\end{array}$ & $\begin{array}{l}0.109^{\star * *} \\
(0.00)\end{array}$ & $\begin{array}{l}0.040^{* \star \star} \\
(0.00)\end{array}$ \\
\hline LEVERAGE & $\begin{array}{c}-1.847^{\star \star} \\
(0.01)\end{array}$ & $\begin{array}{c}-0.340 \\
(0.28)\end{array}$ & $\begin{array}{c}-3.757^{* *} \\
(0.01)\end{array}$ & $\begin{array}{c}-0.140 \\
(0.47)\end{array}$ & $\begin{array}{l}-1.060^{\star \star *} \\
(0.00)\end{array}$ & $\begin{array}{l}-1.443^{\star \star} \\
(0.02)\end{array}$ & $\begin{array}{c}-2.906 \\
(0.11)\end{array}$ & $\begin{array}{c}-0.160 \\
(0.93)\end{array}$ & $\begin{array}{l}-1.697^{* * *} \\
(0.00)\end{array}$ & $\begin{array}{c}-1.930^{* *} \\
(0.02)\end{array}$ & $\begin{array}{c}-2.146 \\
(0.22)\end{array}$ & $\begin{array}{c}-0.203 \\
(0.70)\end{array}$ & $\begin{array}{c}-0.811 \\
(0.20)\end{array}$ & $\begin{array}{c}-0.028 \\
(0.40)\end{array}$ \\
\hline CASH_RATIO & $\begin{array}{l}5.420^{* * *} \\
(0.00)\end{array}$ & $\begin{array}{l}0.674^{* *} \\
(0.04)\end{array}$ & $\begin{array}{c}-1.934 \\
(0.20)\end{array}$ & $\begin{array}{l}0.823^{\star *} \\
(0.02)\end{array}$ & $\begin{array}{l}1.229^{\star \star \star} \\
(0.00)\end{array}$ & $\begin{array}{l}2.334^{\star \star \star} \\
(0.00)\end{array}$ & $\begin{array}{l}8.300^{\star \star} \\
(0.03)\end{array}$ & $\begin{array}{l}6.074^{*} \\
(0.09)\end{array}$ & $\begin{array}{l}2.380^{* * *} \\
(0.00)\end{array}$ & $\begin{array}{l}1.400 \\
(0.34)\end{array}$ & $\begin{array}{l}2.772 \\
(0.44)\end{array}$ & $\begin{array}{l}5.741^{\star \star \star} \\
(0.00)\end{array}$ & $\begin{array}{l}5.099^{\star \star \star} \\
(0.00)\end{array}$ & $\begin{array}{l}1.251^{\star \star \star} \\
(0.00)\end{array}$ \\
\hline \%_INSIDER & $\begin{array}{c}0.005 \\
(0.49)\end{array}$ & $\begin{array}{l}0.008^{* *} \\
(0.05)\end{array}$ & $\begin{array}{l}-0.022^{\star \star \star} \\
(0.00)\end{array}$ & $\begin{array}{l}0.002^{\star \star} \\
(0.04)\end{array}$ & $\begin{array}{l}0.002^{*} \\
(0.10)\end{array}$ & $\begin{array}{c}-0.005 \\
(0.15)\end{array}$ & $\begin{array}{c}0.022 \\
(0.16)\end{array}$ & $\begin{array}{c}0.001 \\
(0.90)\end{array}$ & $\begin{array}{c}-0.011^{\star *} \\
(0.02)\end{array}$ & $\begin{array}{c}-0.003 \\
(0.73)\end{array}$ & $\begin{array}{c}0.131 \\
(0.23)\end{array}$ & $\begin{array}{l}0.008^{\star \star} \\
(0.01)\end{array}$ & $\begin{array}{l}0.008^{\star} \\
(0.07)\end{array}$ & $\begin{array}{c}-0.000 \\
(0.88)\end{array}$ \\
\hline \%_INSTITUTIONAL & $\begin{array}{l}0.040^{\star \star \star} \\
(0.00)\end{array}$ & $\begin{array}{l}0.007^{\star *} \\
(0.01)\end{array}$ & $\begin{array}{l}0.018 \\
(0.17)\end{array}$ & $\begin{array}{c}-0.003^{*} \\
(0.06)\end{array}$ & $\begin{array}{l}0.003 \\
(0.13)\end{array}$ & $\begin{array}{c}0.013 \\
(0.17)\end{array}$ & $\begin{array}{c}-0.032 \\
(0.20)\end{array}$ & $\begin{array}{c}-0.006 \\
(0.79)\end{array}$ & $\begin{array}{l}0.006 \\
(0.16)\end{array}$ & $\begin{array}{c}-0.003 \\
(0.72)\end{array}$ & $\begin{array}{c}-0.022 \\
(0.35)\end{array}$ & $\begin{array}{c}0.004 \\
(0.25)\end{array}$ & $\begin{array}{l}0.010^{\text {***}} \\
(0.00)\end{array}$ & $\begin{array}{l}0.002^{\star \star \star} \\
(0.00)\end{array}$ \\
\hline Constant & $\begin{array}{l}1.161 \\
(0.20)\end{array}$ & $\begin{array}{l}1.987^{\star \star *} \\
(0.00)\end{array}$ & $\begin{array}{l}4.976^{\star \star \star} \\
(0.00)\end{array}$ & $\begin{array}{l}1.441^{\star \star \star} \\
(0.00)\end{array}$ & $\begin{array}{l}1.669^{\star \star \star} \\
(0.00)\end{array}$ & $\begin{array}{c}0.784 \\
(0.16)\end{array}$ & $\begin{array}{c}-3.656 \\
(0.19)\end{array}$ & $\begin{array}{l}4.849^{* *} \\
(0.01)\end{array}$ & $\begin{array}{l}1.651^{\star \star \star} \\
(0.00)\end{array}$ & $\begin{array}{l}3.805^{\star * *} \\
(0.00)\end{array}$ & $\begin{array}{l}6.874^{\star \star *} \\
(0.00)\end{array}$ & $\begin{array}{c}0.311 \\
(0.35)\end{array}$ & $\begin{array}{l}0.932^{\star \star *} \\
(0.01)\end{array}$ & $\begin{array}{l}1.158^{\star \star \star} \\
(0.00)\end{array}$ \\
\hline \multirow[t]{2}{*}{$\begin{array}{l}\text { No. of obs. } \\
\text { Adj. } R^{2}\end{array}$} & $\begin{array}{l}2,033 \\
0.113\end{array}$ & $\begin{array}{r}637 \\
0.040\end{array}$ & $\begin{array}{r}471 \\
0.078\end{array}$ & $\begin{array}{r}411 \\
0.323\end{array}$ & $\begin{array}{r}650 \\
0.117\end{array}$ & $\begin{array}{r}904 \\
0.109\end{array}$ & $\begin{array}{r}110 \\
0.331\end{array}$ & $\begin{array}{r}262 \\
0.039\end{array}$ & $\begin{array}{r}175 \\
0.225\end{array}$ & $\begin{array}{r}365 \\
0.163\end{array}$ & $\begin{array}{r}181 \\
0.272\end{array}$ & $\begin{array}{r}250 \\
0.370\end{array}$ & $\begin{array}{l}2,027 \\
0.059\end{array}$ & $\begin{array}{r}13,112 \\
0.152\end{array}$ \\
\hline & & & & & & & & & & & & & \multicolumn{2}{|c|}{ (continued on next page) } \\
\hline
\end{tabular}


TABLE 8 (continued)

Firm Value and Tournament Structure within Country

\begin{tabular}{|c|c|c|c|c|c|c|c|c|c|c|c|c|c|c|}
\hline \multirow[b]{3}{*}{ Variable } & \multicolumn{14}{|c|}{ Dependent Variable: TOBINS_Q } \\
\hline & Australia & Canada & China & France & Germany & $\begin{array}{l}\text { Hong } \\
\text { Kong }\end{array}$ & India & Netherlands & Norway & $\begin{array}{l}\text { South } \\
\text { Africa }\end{array}$ & Sweden & Switzerland & $\begin{array}{l}\text { United } \\
\text { Kingdom }\end{array}$ & $\begin{array}{l}\text { United } \\
\text { States }\end{array}$ \\
\hline & 1 & 2 & 3 & 4 & 5 & 6 & 7 & 8 & 9 & 10 & 11 & 12 & 13 & 14 \\
\hline \multicolumn{15}{|c|}{ Panel B. Firm Value and CEO_PAY_GAP with Nonlinearity } \\
\hline CEO_PAY_GAP & $\begin{array}{l}8.656^{\star \star} \\
(0.01)\end{array}$ & $\begin{array}{c}-1.344^{\star \star} \\
(0.03)\end{array}$ & $\begin{array}{l}7.797^{*} \\
(0.05)\end{array}$ & $\begin{array}{c}-0.039 \\
(0.29)\end{array}$ & $\begin{array}{c}0.116 \\
(0.51)\end{array}$ & $\begin{array}{r}1.577 \\
(0.32)\end{array}$ & $\begin{array}{c}4.638 \\
(0.70)\end{array}$ & $\begin{array}{c}-0.356^{*} \\
(0.07)\end{array}$ & $\begin{array}{c}0.048 \\
(0.95)\end{array}$ & $\begin{array}{l}0.853^{\star \star *} \\
(0.00)\end{array}$ & $\begin{array}{c}0.235 \\
(0.27)\end{array}$ & $\begin{array}{l}0.204^{\star \star \star} \\
(0.01)\end{array}$ & $\begin{array}{l}0.006^{* *} \\
(0.04)\end{array}$ & $\begin{array}{l}0.115^{\star \star *} \\
(0.01)\end{array}$ \\
\hline CEO_PAY_GAP ${ }^{2}$ & $\begin{array}{c}-4.318^{*} \\
(0.10)\end{array}$ & $\begin{array}{l}0.394^{*} \\
(0.09)\end{array}$ & $\begin{array}{c}-2.656^{*} \\
(0.08)\end{array}$ & $\begin{array}{l}0.049^{* * *} \\
(0.00)\end{array}$ & $\begin{array}{c}-0.003 \\
(0.94)\end{array}$ & $\begin{array}{c}-0.180 \\
(0.82)\end{array}$ & $\begin{array}{l}1.425 \\
(0.83)\end{array}$ & $\begin{array}{c}-0.125 \\
(0.16)\end{array}$ & $\begin{array}{c}0.326 \\
(0.60)\end{array}$ & $\begin{array}{c}-0.082^{*} \\
(0.06)\end{array}$ & $\begin{array}{r}0.011 \\
(0.95)\end{array}$ & $\begin{array}{l}-0.026^{\star \star \star} \\
(0.01)\end{array}$ & $\begin{array}{c}-0.202^{\star} \\
(0.08)\end{array}$ & $\begin{array}{c}-0.018^{\star *} \\
(0.04)\end{array}$ \\
\hline $\log ($ REVENUE) & $\begin{array}{l}-0.286^{* * *} \\
(0.00)\end{array}$ & $\begin{array}{c}-0.016 \\
(0.53)\end{array}$ & $\begin{array}{c}0.047 \\
(0.69)\end{array}$ & $\begin{array}{l}0.040^{* *} \\
(0.02)\end{array}$ & $\begin{array}{c}-0.004 \\
(0.81)\end{array}$ & $\begin{array}{l}0.069 \\
(0.17)\end{array}$ & $\begin{array}{l}0.831^{\star} \\
(0.06)\end{array}$ & $\begin{array}{c}-0.324^{*} \\
(0.05)\end{array}$ & $\begin{array}{l}0.077^{\star} \\
(0.09)\end{array}$ & $\begin{array}{c}0.080 \\
(0.62)\end{array}$ & $\begin{array}{c}-0.256^{*} \\
(0.09)\end{array}$ & $\begin{array}{l}0.139^{\star \star \star} \\
(0.00)\end{array}$ & $\begin{array}{l}0.110^{\star \star *} \\
(0.00)\end{array}$ & $\begin{array}{l}0.039^{\star \star \star} \\
(0.00)\end{array}$ \\
\hline LEVERAGE & $\begin{array}{l}-1.827^{\star *} \\
(0.01)\end{array}$ & $\begin{array}{c}-0.328 \\
(0.30)\end{array}$ & $\begin{array}{l}-3.874^{\star *} \\
(0.01)\end{array}$ & $\begin{array}{c}-0.234 \\
(0.22)\end{array}$ & $\begin{array}{l}-1.056^{\star * *} \\
(0.00)\end{array}$ & $\begin{array}{l}-1.433^{\star \star} \\
(0.03)\end{array}$ & $\begin{array}{c}-2.921 \\
(0.11)\end{array}$ & $\begin{array}{c}-0.293 \\
(0.88)\end{array}$ & $\begin{array}{l}-1.696^{* * *} \\
(0.00)\end{array}$ & $\begin{array}{c}-1.930^{* *} \\
(0.02)\end{array}$ & $\begin{array}{r}-2.147 \\
(0.22)\end{array}$ & $\begin{array}{c}-0.152 \\
(0.77)\end{array}$ & $\begin{array}{c}-0.797 \\
(0.21)\end{array}$ & $\begin{array}{c}-0.029 \\
(0.37)\end{array}$ \\
\hline CASH_RATIO & $\begin{array}{l}5.424^{* * *} \\
(0.00)\end{array}$ & $\begin{array}{l}0.647^{\star *} \\
(0.05)\end{array}$ & $\begin{array}{c}-1.922 \\
(0.20)\end{array}$ & $\begin{array}{l}0.761^{* *} \\
(0.03)\end{array}$ & $\begin{array}{l}1.223^{\star \star \star} \\
(0.00)\end{array}$ & $\begin{array}{l}2.341^{\star \star *} \\
(0.00)\end{array}$ & $\begin{array}{l}8.234^{\star \star} \\
(0.04)\end{array}$ & $\begin{array}{l}5.781^{*} \\
(0.10)\end{array}$ & $\begin{array}{l}2.395^{\star * *} \\
(0.00)\end{array}$ & $\begin{array}{r}1.401 \\
(0.34)\end{array}$ & $\begin{array}{l}2.769 \\
(0.45)\end{array}$ & $\begin{array}{l}5.937^{\star \star \star} \\
(0.00)\end{array}$ & $\begin{array}{l}5.112^{\star \star \star} \\
(0.00)\end{array}$ & $\begin{array}{l}1.251^{\star \star \star} \\
(0.00)\end{array}$ \\
\hline \%_INSIDER & $\begin{array}{l}0.005 \\
(0.54)\end{array}$ & $\begin{array}{l}0.006^{*} \\
(0.11)\end{array}$ & $\begin{array}{l}-0.022^{* * *} \\
(0.00)\end{array}$ & $\begin{array}{l}0.003^{* *} \\
(0.03)\end{array}$ & $\begin{array}{l}0.002^{*} \\
(0.10)\end{array}$ & $\begin{array}{c}-0.005 \\
(0.16)\end{array}$ & $\begin{array}{l}0.022 \\
(0.19)\end{array}$ & $\begin{array}{c}0.001 \\
(0.88)\end{array}$ & $\begin{array}{l}-0.011^{* *} \\
(0.02)\end{array}$ & $\begin{array}{c}-0.003 \\
(0.74)\end{array}$ & $\begin{array}{c}0.131 \\
(0.23)\end{array}$ & $\begin{array}{l}0.009^{* *} \\
(0.01)\end{array}$ & $\begin{array}{l}0.008^{\star} \\
(0.07)\end{array}$ & $\begin{array}{c}-0.000 \\
(0.87)\end{array}$ \\
\hline \%_INSTITUTIONAL & $\begin{array}{l}0.040^{\star * *} \\
(0.00)\end{array}$ & $\begin{array}{l}0.007^{* *} \\
(0.01)\end{array}$ & $\begin{array}{l}0.017 \\
(0.18)\end{array}$ & $\begin{array}{c}-0.004^{\star *} \\
(0.03)\end{array}$ & $\begin{array}{l}0.003 \\
(0.14)\end{array}$ & $\begin{array}{c}0.013 \\
(0.18)\end{array}$ & $\begin{array}{c}-0.032 \\
(0.21)\end{array}$ & $\begin{array}{c}-0.006 \\
(0.80)\end{array}$ & $\begin{array}{c}0.006 \\
(0.17)\end{array}$ & $\begin{array}{c}-0.003 \\
(0.72)\end{array}$ & $\begin{array}{c}-0.022 \\
(0.35)\end{array}$ & $\begin{array}{c}0.004 \\
(0.20)\end{array}$ & $\begin{array}{l}0.010^{\star \star *} \\
(0.00)\end{array}$ & $\begin{array}{l}0.002^{\star * *} \\
(0.00)\end{array}$ \\
\hline Constant & $\begin{array}{c}-0.500 \\
(0.71)\end{array}$ & $\begin{array}{l}2.452^{\star \star \star} \\
(0.00)\end{array}$ & $\begin{array}{l}1.323 \\
(0.54)\end{array}$ & $\begin{array}{l}1.483^{* \star \star} \\
(0.00)\end{array}$ & $\begin{array}{l}1.662^{\star \star \star} \\
(0.00)\end{array}$ & $\begin{array}{c}0.656 \\
(0.41)\end{array}$ & $\begin{array}{c}-3.348 \\
(0.37)\end{array}$ & $\begin{array}{l}4.605^{* *} \\
(0.01)\end{array}$ & $\begin{array}{l}1.698^{* * *} \\
(0.00)\end{array}$ & $\begin{array}{l}3.784^{* * *} \\
(0.00)\end{array}$ & $\begin{array}{l}6.859^{\star * \star} \\
(0.00)\end{array}$ & $\begin{array}{c}0.176 \\
(0.59)\end{array}$ & $\begin{array}{l}0.768^{*} \\
(0.06)\end{array}$ & $\begin{array}{l}1.116^{\star \star \star} \\
(0.00)\end{array}$ \\
\hline $\begin{array}{l}\text { No. of obs. } \\
R^{2}\end{array}$ & $\begin{array}{l}2,033 \\
0.113\end{array}$ & $\begin{array}{r}637 \\
0.136\end{array}$ & $\begin{array}{r}471 \\
0.184\end{array}$ & $\begin{array}{r}411 \\
0.371\end{array}$ & $\begin{array}{r}650 \\
0.116\end{array}$ & $\begin{array}{r}904 \\
0.163\end{array}$ & $\begin{array}{r}110 \\
0.332\end{array}$ & $\begin{array}{r}262 \\
0.196\end{array}$ & $\begin{array}{r}175 \\
0.230\end{array}$ & $\begin{array}{r}365 \\
0.119\end{array}$ & $\begin{array}{r}181 \\
0.272\end{array}$ & $\begin{array}{r}250 \\
0.383\end{array}$ & $\begin{array}{l}2,027 \\
0.149\end{array}$ & $\begin{array}{r}13,112 \\
0.153\end{array}$ \\
\hline
\end{tabular}


countries in which tournament effects appear to be considerable, there may be limits on the size of the pay difference. In fact, we find that the pay gap increases firm value at a decreasing rate for those countries in which pay differences are associated with an increase in firm value.

Overall, the results in Table 8 support our hypothesis that firm value is related to tournament structure, as suggested by the theories (e.g., Lazear and Rosen (1981)). This evidence for a number of countries supports the evidence in Kale et al. (2009) of such a relationship for the United States.

\section{Conclusions}

The degree to which the CEO tournament structure is influenced by cultural factors, and the success of such a structure in terms of enhanced firm value, are two issues that we address through a comprehensive analysis of cross-country differences in executive compensation tournament structure. In testing for the determinants of CEO tournament structures, we find that the tournament structure is steeper in U.S. companies as compared to foreign companies. Our results indicate that this can be partially explained by cultural influences, which include measures of the acceptability of power, income differentials, and the desirability of competition. Our regressions also suggest that the interaction of culture and tournament affects the CEO tournament's impact on firm value. Steeper tournaments can be more effective at improving firm value in countries that value competition, power, and fairness in income. We find that a steeper tournament structure appears to lead to better performance generally across firms in our sample from a number of different countries. However, the pay gap increases firm value at a decreasing rate for those countries in which pay differences are associated with an increase in firm value.

Overall, our analysis supports the hypothesis that tournaments are an important incentive mechanism for motivating corporate managers and further that tournaments lead to improved firm performance. In countries that value power distance, competition, and differences in income due to differing levels of efficiency, tournaments are steeper and appear to be even more effective.

Further, Hofstede $(1980,2001)$ argues that differences in organizations across countries reflect differences in cultural beliefs across the countries. Consistent with this conjecture, Aggarwal, Erel, Stulz, and Williamson (2010) find systematic differences in governance practices across countries. Such organizational differences also include differences in boards of directors, who make the decisions on CEO promotion and compensation structures. For example, the composition of boards in Germany, which require substantial labor representation on the board, vary quite a bit from the composition of boards in the United Kingdom. Similarly, composition of boards in countries that have a gender quota will differ from those in other countries that do not. These differences in board composition, which arise from differences in shared values (i.e., culture), should also lead to differences in attitudes regarding CEO tournament structures. Firms must balance tournament-creating incentives with turnover costs. Recent research by Kale et al. (2014) shows that, in the United States, vice president turnover is higher in firms with steeper tournaments. Turnover rates may also vary across countries 
and possibly affect the relation between tournaments and value creation. Finally, our measures use reported compensation that do not take into account other benefits that are unreported; for instance, Kato and Long (2006) estimate executives perks as $15 \%-32 \%$ of compensation in Chinese firms. These perks likely increase with compensation and therefore the steepness of our tournament for China may be understated. These unreported perks also likely vary with the tax structure and culture of countries. Future research could focus on these differences and their relations to CEO tournament structures and consequences.

\section{Appendix A. Cultural, Legal, and Economic Variable Definitions}

POWER_DISTANCE The degree to which people in the society are comfortable with power differentials, where higher numbers correspond to more comfort with power differentials. Source: Hofstede (1980).

INDIVIDUALISM The degree to which people in the society are individualistic. Higher scores imply higher individualism. Source: Hofstede (1980).

FAIR_INCOME_DIFFERENCES The degree to which people in a society consider differences in income to be fair based on the answer to the question: Imagine two secretaries, of the same age, doing practically the same job. One finds out that the other earns considerably more than she does. The better paid secretary, however, is quicker, more efficient, and more reliable at her job. In your opinion, is it fair or not fair that one secretary is paid more than the other? A value of 1 is Fair; 0 is Not Fair. Our measure is the $\%$ positive responses in a country $-\%$ negative responses +100 . Thus, the range is from 0 (corresponding to Not Fair) to 200 (corresponding to Fair). Source: World Values Survey.

INCOME_INEQUALITY The degree to which people in a society believe that income differences can provide incentives: Incomes should be made more equal versus we need larger income differences as incentives, scale of 1 to 10 , where a value of 10 is "We need larger income differences as incentives." We measure the average response. Higher numbers correspond to income differences being perceived as desirable. Source: World Values Survey.

HARDWORK The degree to which people in a society believe hard work brings success versus hard work does not generally bring success; it is more a matter of luck and connections. Scale of 1 to 10 , where 10 is "Hard work doesn't generally bring success; it's more a matter of luck and connections." Source: World Values Survey. (We measure the average response, but reverse the sign so that less negative numbers correspond to hard work being more desirable.)

COMPETITION The degree to which people in a society believe competition to be good: it stimulates people to work hard and develop new ideas versus competition is harmful. It brings out the worst in people. Scale of 1 to 10, where 10 is "Competition is harmful." Source: World Values Survey. (We measure the average response, but reverse the sign so that less negative numbers correspond to competition being more desirable.)

LEGAL (SPAMANN $\times$ ROL) Measure of a county's legal environment using the Durnev and Kim (2005) LEGAL variable, equal to the product of antidirector rights and rule of law, where the antidirector rights index is from Spamann (2010).

GINI The GINI coefficient measures the inequality among values of a frequency distribution (e.g., levels of income). A GINI coefficient of 0 expresses perfect equality where 
all values are the same (e.g., where everyone has an exactly equal income). A GINI coefficient of 1 (100 on the percentile scale) expresses maximal inequality among values (e.g., where only 1 person has all the income).

$\log (\mathrm{GNP})$ Log of the country's GNP.

\section{Appendix B. Questions from the WVS}

In Appendix B, for the four World Value Survey measures we include in the analysis, we provide the wording of the actual survey questions.

Fair income differences: Imagine two secretaries, of the same age, doing practically the same job. One finds out that the other earns considerably more than she does. The better paid secretary, however, is quicker, more efficient, and more reliable at her job. In your opinion, is it fair or not fair that one secretary is paid more than the other?

0 Not Fair

1 Fair

Income inequality: How would you place your views on this scale? 1 means you agree completely with the statement on the left; 10 means you agree completely with the statement on the right; and if your views fall somewhere in between, you can choose any number in between. Sentences:

Incomes should be made more equal vs. We need larger income differences as incentives

Hardwork: How would you place your views on this scale? 1 means you agree completely with the statement on the left; 10 means you agree completely with the statement on the right; and if your views fall somewhere in between, you can choose any number in between.

In the long run, hard work usually brings a better life vs. Hard work doesn't generally bring success - it's more a matter of luck and connections.

Competition: How would you place your views on this scale? 1 means you agree completely with the statement on the left; 10 means you agree completely with the statement on the right; and if your views fall somewhere in between, you can choose any number in between. Sentences:

Competition is good. It stimulates people to work hard and develop new ideas vs. Competition is harmful. It brings out the worst in people.

\section{Appendix C. Country Cultural, Legal, and Economic Measures}

In Appendix C, we report on the country cultural, legal, and economic measures. For each of the 14 countries in our sample, we provide the magnitudes of the following variables in Table C1: POWER_DISTANCE and INDIVIDUALISM from Hofstede (1980); FAIR_INCOME_DIFFERENCE, INCOME_INEQUALITY, HARDWORK, and COMPETITION from the WVS (2005-2009); the LEGAL variable from Durnev and Kim (2005); the GINI coefficient from the U.S. Central Intelligence Agency; and GNP_PER_CAPITA from the World Bank's World Development Indicators Database. 
TABLE C1

Country Cultural, Legal, and Economic Measures

For the 14 countries in the sample, Table $\mathrm{C} 1$ reports the country's cultural, legal, and economic measures, which are derived from Hofstede (1980), the WVS (2005-2009), Durnev and Kim (2005), the CIA, and the World Bank's World Development Indicators Database.

\begin{tabular}{|c|c|c|c|c|c|c|c|c|c|}
\hline Country & 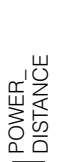 & 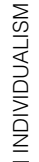 & 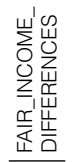 & 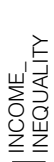 & 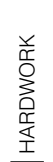 & 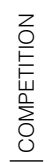 & $\begin{array}{l}\vec{\varangle} \\
\circlearrowleft \\
\Psi\end{array}$ & $\underset{\bar{c}}{\bar{\Sigma}}$ & 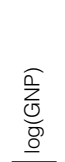 \\
\hline Australia & 36 & 90 & 167.66 & 5.67 & 4.31 & 3.77 & 40 & 30.5 & 10.52 \\
\hline Canada & 39 & 80 & 158.37 & 5.56 & 3.95 & 3.79 & 40 & 32.1 & 10.53 \\
\hline China & 80 & 20 & 174.21 & 5.9 & 3.63 & 3.27 & & 41.5 & 7.88 \\
\hline France & 68 & 71 & 154.43 & 5.07 & 5.17 & 4.96 & 31.43 & 32.7 & 10.57 \\
\hline Germany & 35 & 67 & 166.82 & 4.35 & 5.04 & 3.76 & 32.31 & 27 & 10.57 \\
\hline Hong Kong & 68 & 25 & 171.92 & 4.78 & & 3.81 & 41.1 & 53.3 & 10.3 \\
\hline India & 77 & 48 & 130.74 & 4.72 & 3.33 & 2.83 & 22.1 & 36.8 & 7.47 \\
\hline Netherlands & 38 & 80 & 150.96 & 5.81 & 5.04 & 4.63 & 25 & 30.9 & 10.71 \\
\hline Norway & 31 & 69 & 109.71 & 5.31 & 5.02 & 3.53 & 35 & 25 & 11.04 \\
\hline South Africa & 49 & 65 & 125.85 & 5.53 & 3.01 & 3.51 & 22.1 & 65 & 8.59 \\
\hline Sweden & 31 & 71 & 160.77 & 5.99 & 4.55 & 3.42 & 35 & 23 & 10.78 \\
\hline Switzerland & 34 & 68 & 167.84 & 4.43 & 5.28 & 3.7 & 30 & 33.7 & 10.96 \\
\hline United Kingdom & 35 & 89 & 146.51 & 5.46 & 4.62 & 4.1 & 42.85 & 34 & 10.65 \\
\hline United States & 40 & 91 & 181.45 & 6.1 & 3.81 & 3.43 & 30 & 45 & 10.74 \\
\hline
\end{tabular}

\section{References}

Abowd, J., and D. Kaplan. "Executive Compensation: Six Questions that Need Answering.” Journal of Economic Perspectives, 13 (1999), 145-167.

Aggarwal, R.; I. Erel; and L. Starks. "Influence of Opinion on Investor Voting and Proxy Advisors." Working Paper, Georgetown University (2015).

Aggarwal, R.; I. Erel; R. Stulz; and R. Williamson. "Differences in Governance Practices between U.S. and Foreign Firms: Measurement, Causes, and Consequences." Review of Financial Studies, 23 (2010), 3131-3169.

Agrawal, A.; C. Knoeber; and F. Tsoulouhas. "Are Outsiders Handicapped in CEO Successions?" Journal of Corporate Finance, 12 (2006), 619-644.

Ahern, K.; D. Daminelli; and C. Fracassi. "Lost in Translation? The Effect of Cultural Values on Mergers around the World." Journal of Financial Economics, 117 (2015), 165-189.

Aoki, M. "Toward an Economic Model of the Japanese Firm." Journal of Economic Literature, 28 (1990), 1-27.

Audas, R.; T. Barmby; and J. Treble. "Luck, Effort, and Reward in an Organizational Hierarchy." Journal of Labor Economics, 22 (2004), 379-395.

Baker, G. P.; M. C. Jensen; and K. J. Murphy. "Compensation and Incentives: Practice vs. Theory." Journal of Finance, 43 (1988), 593-616.

Bebchuk, L.; K. M. Cremers; and U. Peyer. "The CEO Pay Slice.” Journal of Financial Economics, 102 (2011), 199-221.

Bebchuk, L. A.; J. M. Fried; and D. I. Walker. "Managerial Power and Rent Extraction in the Design of Executive Compensation." University of Chicago Law Review, 69 (2003), 751-846.

Becker, G. "Preferences and Values." In Accounting for Tastes, Gary Becker, ed. Cambridge: Harvard University Press (1996).

Bogaard, H., and C. Pirinsky. "Cultural Heritage and Financial Development." Working Paper, George Washington University (2011).

Bognanno, M. "Corporate Tournaments." Journal of Labor Economics, 19 (2001), 290-315.

Brown, K.; V. Harlow; and L. Starks. "Of Tournaments and Temptations: An Analysis of Managerial Incentives in the Mutual Fund Industry." Journal of Finance, 51 (1996), 85-110.

Bryan, S.; R. Nash; and A. Patel. "Culture and CEO Compensation." Working Paper, Fordham University and Wake Forest University (2012).

Cheffins, B. R. "Corporate Governance in the United Kingdom: Lessons for Canada." Canadian Business Law Journal, 28 (1997), 69-106.

Chen, Y.; P. Dou; G. Rhee; C. Truong; and M. Veeraraghavan. "National Culture and Corporate Cash Holdings around the World." Journal of Banking and Finance, 50 (2015), 1-18. 
Chen, Y.; E. Podolski; G. Rhee; and M. Veeraraghavan. "Local Gambling Preferences and Corporate Innovative Success." Journal of Financial and Quantitative Analysis, 49 (2014), 77-106.

Chui, A.; S. Titman; and J. Wei. "Individualism and Momentum around the World." Journal of Finance, 65 (2010), 361-392.

Coles, J.; Z. Li; and Y. Wang. "Industry Tournament Incentives.” Working Paper, Arizona State University (2013).

Conyon, M.; J. Core; and W. Guay. "Are U.S. CEOs Paid More than U.K. CEOs? Inferences from Risk-Adjusted Pay." Review of Financial Studies, 24 (2011), 402-438.

Conyon, M., and K. J. Murphy. "The Prince and the Pauper? CEO Pay in the United States and United Kingdom.” The Economic Journal, 110 (2000), 640-671.

Conyon, M.; S. Peck; and G. Sadler. "Corporate Tournaments and Executive Compensation: Evidence from the U.K." Strategic Management Journal, 22 (2001), 805-815.

Core, J.; R. Holthausen; and D. Larcker. "Corporate Governance, Chief Executive Officer Compensation, and Firm Performance.” Journal of Financial Economics, 51 (1999), 371-406.

Cronqvist, H.; A. Makhija; and S. Yonker. "Behavioral Consistency in Corporate Finance: CEO Personal and Corporate Leverage." Journal of Financial Economics, 103 (2011), 20-40.

Cyert, R.; S. Kang; and P. Kumar. "Corporate Governance, Takeovers and Top-Management Compensation: Theory and Evidence.” Management Science, 48 (2002), 453-469.

Dittman, I.; E. Maug; and O. Spalt. "Sticks or Carrots? Optimal CEO Compensation When Managers Are Loss Averse." Journal of Finance, 65 (2010), 2015-2050.

Dodor, J., and D. S. Rana. "Culture and Economic Development: An Investigation Using Hofstede Cultural Dimensions.” International Journal of Business Research, 7 (2007), 75-84.

Doidge, C.; G. A. Karolyi; and R. Stulz. "Why Do Countries Matter So Much for Corporate Governance?” Journal of Financial Economics, 86 (2007), 1-39.

Durnev, A., and E. H. Kim. "To Steal or Not To Steal: Firm Attributes, Legal Environment, and Valuation." Journal of Finance, 60 (2005), 1461-1493.

Easterlin, R. "Will Raising the Incomes of All Increase the Happiness of All?" Journal of Economic Behavior and Organization, 27 (1995), 35-47.

Easterlin, R. "Income and Happiness: Toward a Unified Theory." Economic Journal, 111 (2001), $465-484$.

Eriksson, T. "Executive Compensation and Tournament Theory: Empirical Tests on Danish Data." Journal of Labor Economics, 17 (1999), 262-280.

Ertimur, Y.; F. Ferri; and V. Muslu. "Shareholder Activism and CEO Pay." Review of Financial Studies, 24 (2011), 535-592.

Fernandes, N.; M. Ferreira; P. Matos; and K. J. Murphy. "Are U.S. CEOs Paid More? New International Evidence.” Review of Financial Studies, 26 (2013), 323-367.

Ferris, S.; N. Jayaraman; and S. Sabherwal. "CEO Overconfidence and International Merger and Acquisition Activity.” Journal of Financial and Quantitative Analysis, 48 (2013), 137-164.

Frank, R., and P. J. Cook. The Winner-Take-All Society. New York, NY: Free Press (1995).

Frey, B. S., and A. Stutzer. "What Can Economists Learn from Happiness Research?" Journal of Economic Literature, 40 (2002a), 402-435.

Frey, B. S., and A. Stutzer. Happiness in Economics. Princeton, NJ: Princeton University Press (2002b).

Frijns, B.; A. Gilbert; T. Lehnert; and A. Tourani-Rad. "Cultural Values, CEO Risk Aversion and Corporate Takeovers." Journal of Corporate Finance, 15 (2011), 543-561.

Gervais, S.; J. B. Heaton; and T. Odean. "Overconfidence, Compensation Contracts, and Capital Budgeting." Journal of Finance, 66 (2011), 1735-1777.

Goldman Sachs. "GS SUSTAIN: Counting on Compensation: A Focus on Pay and Performance." Nov. 13 (2013).

Goyal, V. K., and C. W. Park. "Board Leadership Structure and CEO Turnover." Journal of Corporate Finance: Contracting, Governance \& Organization, 8 (2002), 49-66.

Graham, J.; C. Harvey; and M. Puri. "Managerial Attitudes and Corporate Actions." Journal of Financial Economics, 109 (2013), 103-121.

Granato, J.; R. Inglehart; and D. Leblang. "The Effect of Cultural Values on Economic Development: Theory, Hypotheses, and Some Empirical Tests.” American Journal of Political Science, 40 (1996), 607-631.

Green, J., and N. Stokey. "A Comparison of Tournaments and Contracts." Journal of Political Economy, 91 (1983), 349-364.

Guiso, L.; P. Sapienza; and L. Zingales. "Does Culture Affect Economic Outcomes?" Journal of Economic Perspectives, 20 (2006), 23-48.

Guiso, L.; P. Sapienza; and L. Zingales. "Trusting the Stock Market.” Journal of Finance, 63 (2008), 2557-2600. 
Guiso, L.; P. Sapienza; and L. Zingales. "Cultural Biases in Economic Exchange?” Quarterly Journal of Economics, 124 (2009), 1095-1131.

Hartzell, J., and L. Starks. "Institutional Investors and Executive Compensation." Journal of Finance, 58 (2003), 2351-2374.

Henderson, A., and J. Fredrickson. "Top Management Team Coordination Needs and the CEO Pay Gap: A Competitive Test of Economic and Behavioral Views." Academy of Management Journal, 44 (2001), 96-117.

Hofstede, G. Culture's Consequences: International Differences in Work-Related Values. Newbury Park, CA: Sage Publications (1980).

Hofstede, G. Culture's Consequences: Comparing Values, Behaviors, Institutions, and Organizations across Nations. Thousand Oaks, CA: Sage Publications (2001).

Huson, M.; R. Parrino; and L. Starks. "Internal Monitoring Mechanisms and CEO Turnovers: A LongTerm Perspective.” Journal of Finance, 56 (2001), 2265-2297.

Kale, J.; E. Reis; and A. Venkateswaran. "Rank-Order Tournaments and Incentive Alignment: The Effect on Firm Performance." Journal of Finance, 64 (2009), 1479-1512.

Kale, J.; E. Reis; and A. Venkateswaran. "Pay Inequalities and Managerial Turnover." Journal of Empirical Finance, 27 (2014), 31-39.

Kaltenthaler, K.; S. Ceccoli; and R. Gelleny. "Attitudes toward Eliminating Income Inequality in Europe." European Union Politics, 9 (2008), 217-241.

Kaplan, S. "Top Executive Rewards and Firm Performance: A Comparison of Japan and the United States." Journal of Political Economy, 102 (1994), 510-546.

Karolyi, G. A. "The Gravity of Culture for Finance." Journal of Corporate Finance, 41 (2016), 610-625.

Kato, T., and C. Long. "Executive Compensation, Firm Performance, and Corporate Governance in China: Evidence from Firms Listed in the Shanghai and Shenzhen Stock Exchanges." Economic Development and Cultural Change, 54 (2006), 945-983.

Kempf, A.; S. Ruenzi; and T. Thiele. "Employment Risk, Compensation Incentives, and Managerial Risk-Taking: Evidence from the Mutual Fund Industry." Journal of Financial Economics, 92 (2009), 92-108.

Kuhnen, C., and A. Niessen. "Public Opinion and Executive Compensation." Management Science, 58 (2012), 1249-1272.

Kumar, A.; J. Page; and O. Spalt. "Religious Beliefs, Gambling Attitudes, and Financial Market Outcomes.” Journal of Financial Economics, 102 (2011), 671-708.

La Porta, R.; F. Lopez-de-Silanes; A. Shleifer; and R. Vishny. "Legal Determinants of External Finance." Journal of Finance, 52 (1997), 1131-1150.

La Porta, R.; F. Lopez-de-Silanes; A. Shleifer; and R. Vishny. "Law and Finance." Journal of Political Economy, 106 (1998), 1113-1154.

Lazear, E., and S. Rosen. "Rank-Order Tournaments as Optimum Labor Contracts." Journal of Political Economy, 89 (1981), 841-864.

Lee, K.; B. Lev; and G. Yeo. "Executive Pay Dispersion, Corporate Governance, and Firm Performance." Review of Quantitative Finance \& Accounting, 30 (2008), 315-338.

Li, K.; D. Griffin; H. Yue; and L. Zhao. "How Does Culture Influence Corporate Risk Taking?" Journal of Corporate Finance, 23 (2013), 1-22.

Malmiender, U., and G. Tate. "CEO Overconfidence and Corporate Investment." Journal of Finance, 60 (2005), 2661-2700.

Mehran, H. "Executive Compensation Structure, Ownership, and Firm Performance." Journal of Financial Economics, 38 (1995), 163-184.

Murphy, K. J. "Executive Compensation." In Handbook of Labor Economics, O. Ashenfelter and D. Card, eds. Amsterdam: Elsevier Science, North-Holland (1999).

Murphy, K. J. "Executive Compensation: Where We Are and How We Got There." In Handbook of the Economics of Finance, G. Constantinides, M. Harris, and R. Stulz, eds. Amsterdam: Elsevier Science, North-Holland (2013).

Muslu, V. "Executive Directors, Pay Disclosures, and Incentive Compensation in Large European Companies." Journal of Accounting, Auditing \& Finance, 25 (2010), 569-605.

Nalebuff, B., and J. Stiglitz. "Prizes and Incentives: Toward a General Theory of Compensation and Competition.” Bell Journal of Economics, 14 (1983), 21-43.

Pan, C., and C. Pirinsky. "Social Influence in the Housing Market." Journal of Financial and Quantitative Analysis, 50 (2015), 757-779.

Parrino, R. "CEO Turnover and Outside Succession: A Cross-Sectional Analysis." Journal of Financial Economics, 46 (1997), 165-197.

Petersen, M. A. "Estimating Standard Errors in Finance Panel Data Sets: Comparing Approaches." Review of Financial Studies, 22 (2009), 435-480. 
Rajgopal, S., and S. Srinivasan. "Pay Dispersion in the Executive Suite." Working Paper, University of Washington and University of Chicago (2006).

Ramakrishnan, R. T. S., and A. Thakor. "Cooperation versus Competition in Agency." Journal of Law, Economics, and Organizations, 7 (1991), 248-283.

Rosen, S. "Prizes and Incentives in Elimination Tournaments." American Economic Review, 76 (1986), 701-715.

Schwartz, S. "A Theory of Cultural Values and Some Implications for Work." Applied Psychology, 48 (1999), 23-47.

Siegel, J.; A. Licht; and S. Schwartz. "Egalitarianism, Cultural Distance, and Foreign Direct Investment: A New Approach." Organization Science, 24 (2013), 1174-1194.

Spamann, H. "The Antidirector Rights Index Revisited." Review of Financial Studies, 23 (2010), $467-486$.

Stulz, R., and R. Williamson. "Culture, Openness, and Finance." Journal of Financial Economics, 70 (2003), 313-349.

Surkov, S. "Psychological Aspects of Economic Behavior of People." Universal Journal of Management, 2 (2014), 40-47.

Thomas, R. "Explaining the International CEO Pay Gap: Board Capture or Market Driven?" Vanderbilt Law Review, 57 (2004), 1171-1267.

Titman, S.; J. Wei; and F. Xie. "Market Development and the Asset Growth Effect." Journal of Financial and Quantitative Analysis, 48 (2013), 1405-1432.

Tosi, H., and T. Greckhamer. "Culture and CEO Compensation." Organization Science, 15 (2004), $657-670$.

Yermack, D. "Higher Market Valuation of Companies with a Small Board of Directors." Journal of Financial Economics, 40 (1996), 185-212. 